\title{
A METEOTSUNAMI CLIMATOLOGY ALONG THE U.S. EAST COAST
}

\author{
Gregory Dusek, Christopher DiVeglio, louis licate, lorraine Heilman, \\ Katie Kirk, Christopher Paternostro, and Ashley Miller
}

\section{About 25 meteotsunamis per year were observed by NOAA tide gauges along the \\ U.S. East Coast with wave heights exceeding I meter in several cases.}

0 $\mathrm{n}$ the afternoon of 13 June 2013 a group of divers in Barnegat Inlet, New Jersey, suddenly found themselves picked up by a large wave and placed over a breakwater toward the entrance of the inlet. Several minutes later a second wave picked them back up and placed them back over the breakwater (Bailey et al. 2014). Nearby eyewitnesses describe a wave about $2 \mathrm{~m}$ in height that crashed into a jetty, knocking several people into the water and resulting in multiple injuries (Bailey et al. 2014). There were other eyewitness reports along the U.S. East Coast of a large wave with impacts similar to what might be expected from a tsunami wave. It quickly became apparent that this large wave was a meteotsunami, or an atmospherically induced ocean wave in the tsunami-

Affiliations: Dusek, DiVeglio, Licate, Heilman, Kirk, Paternostro, and Miller-National Oceanic and Atmospheric Administration/National Ocean Service/Center for Operational Oceanographic Products and Services, Silver Spring, Maryland CORRESPONDING AUTHOR: Gregory Dusek,

gregory.dusek@noaa.gov

The abstract for this article can be found in this issue, following the table of contents.

DOI:I0.II75/BAMS-D-I8-0206.I

A supplement to this article is available online (I0.1175/BAMS-D-18-0206.2)

In final form 22 February 2019

For information regarding reuse of this content and general copyright information, consult the AMS Copyright Policy. frequency band (Bailey et al. 2014; Wertman et al. 2014). An intense squall line, known as a derecho, propagating offshore in the mid-Atlantic, likely generated the wave from an associated atmospheric pressure perturbation, amplified from resonance over the continental shelf and eventual reflection off of the shelf break (Pasquet and Vilibić 2013). The wave was observed at more than 16 National Oceanic and Atmospheric Administration (NOAA) tide gauges, with peak-to-trough wave heights exceeding $0.5 \mathrm{~m}$ at several locations (Fig. 1).

Though meteotsunamis have been known to occur for some time [initially Nomitsu (1935) and later Defant (1961)], the term was only recently accepted by the research community (Rabinovich and Monserrat 1996, 1998). Recent instances of more impactful events occurring in the coastal United States (Bailey et al. 2014; Vilibić et al. 2014b) and Great Lakes (Anderson et al. 2015) have spurred increased interest. In particular, the NOAA National Weather Service is investigating how best to warn on detection of a significant meteotsunami and potentially to forecast hazardous events, which are goals pursued elsewhere as well (Renault et al. 2011; Šepić and Vilibić 2011; Vilibić et al. 2016). To accomplish these goals it is first necessary to have a reliable detection method for meteotsunamis and to understand the frequency, magnitude, and underlying meteorological conditions of meteotsunami occurrence. This paper presents a method for automated detection 
of meteotsunami signals at NOAA tide gauges and then applies this approach to 22 years of water-level observations from 125 gauges along the U.S. East Coast, the Caribbean, and Bermuda.

METEOTSUNAMIS. Meteotsunamis are atmospherically forced ocean waves in the tsunami frequency band with periods ranging from $2 \mathrm{~min}$ to $2 \mathrm{~h}$ (Rabinovich and Monserrat 1996). They are typically caused by moving atmospheric disturbances such as sharp pressure gradients and/or changes in wind speed associated with a range of underlying atmospheric conditions, such as frontal passages, convective systems, squall lines, tropical cyclones, or nor'easters (Monserrat et al. 2006; Pasquet et al. 2013; Vilibić et al. 2016 and many others). The initial ocean wave caused by the atmospheric disturbance is typically quite small on the order of centimeters and it is through Proudman (1929), Greenspan (1956), or shelf (Monserrat et al. 2006; Pattiaratchi and Wijeratne 2015) resonance that the wave reaches a larger opensea height on the order of tens of centimeters prior to reaching the coast. These types of resonance are most significant in places with fairly shallow-water depths (40-160 m; Monserrat et al. 2006) and broad continental shelves, such that the translational speed of the atmospheric disturbance $U$ is equal to the edge wave speed or to the long-wave speed, $c=\sqrt{g h}$ where

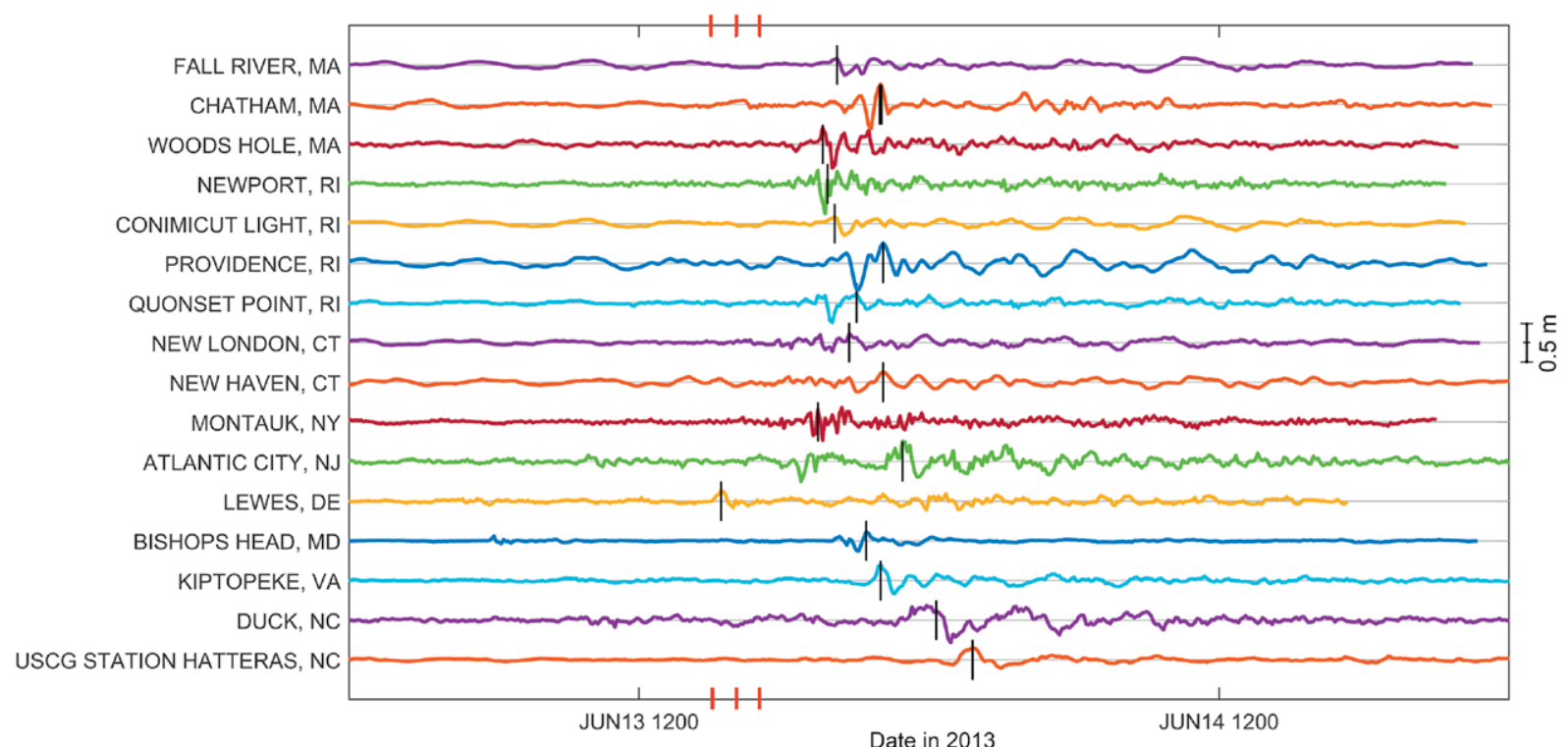

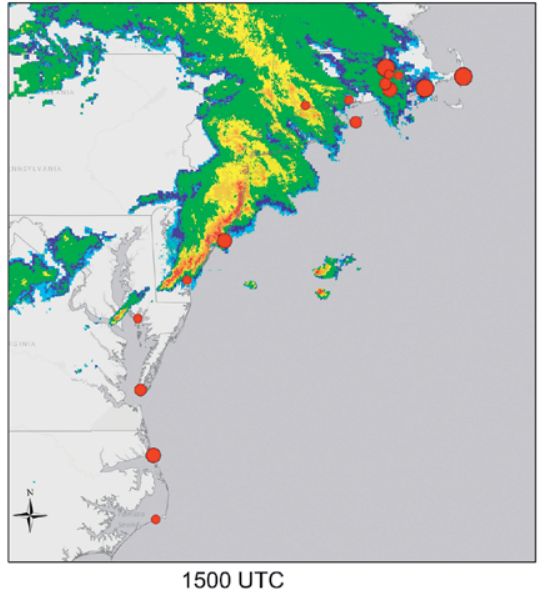

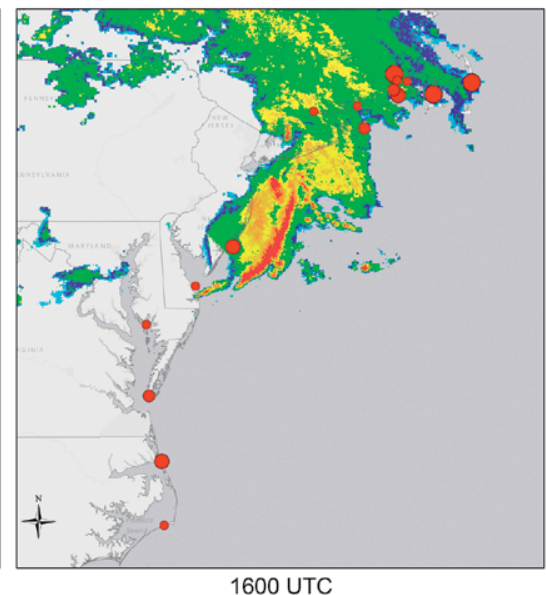

1600 UTC

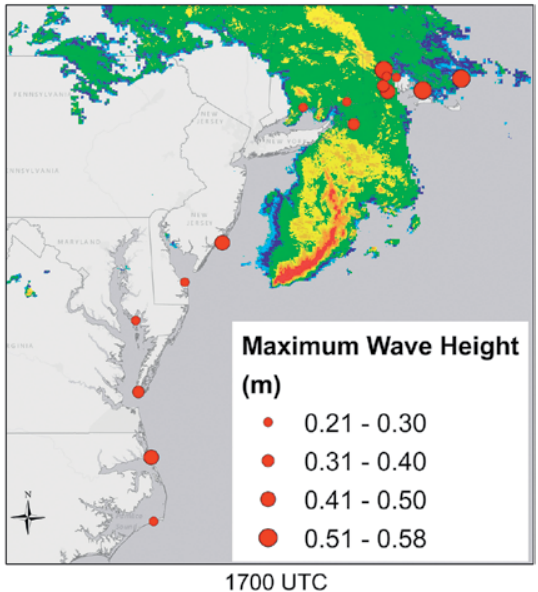

Fig. I. (top) The filtered high-frequency water level and (bottom) the radar imagery and maximum observed wave height for the 13 Jun 2013 meteotsunami. In the top panel, stations are listed generally north to south sorted by state, times of maximum peak-to-trough wave height are identified by the vertical black lines, and spacing between axes indicates a peak-to-trough wave height of $0.5 \mathrm{~m}$. Vertical red lines indicate the times of the radar imagery on 13 Jun. In the bottom panel, the maximum wave heights are shown by the size of the markers. A total of 16 gauges observed the event with a maximum wave height of $0.58 \mathrm{~m}$ at Providence, $\mathbf{R} \mathbf{}$. 
$h$ is water depth. Further amplification of the wave can occur due to harbor resonance (Raichlen 1966), in which the shape of the harbor or estuary is such that oscillations reach an even greater and potentially destructive height.

Meteotsunamis have been observed on coastlines throughout the world's oceans and large lakes (Vilibić et al. 2014a). Observations have been documented along the U.S. East Coast (Pasquet et al. 2013), Gulf Coast (Olabarrieta et al. 2017), Pacific Northwest coast (Thomson et al. 2009), and throughout the Great Lakes (Bechle et al. 2015, 2016; Linares et al. 2016). Meteotsunamis along European coastlines have been observed particularly along the Mediterranean in Spain (Marcos et al. 2009; Rabinovich and Monserrat 1996) and Croatia (Šepić et al. 2009; Šepić et al. 2012), but also in the Black Sea (Šepić et al. 2015), the Netherlands (de Jong and Battjes 2004), the United Kingdom (Ozsoy et al. 2016; Tappin et al. 2013), and elsewhere. In the western Pacific, meteotsunamis have been observed in Japan (Tanaka 2010), China (Wang et al. 1987), Korea (Cho et al. 2013; Choi et al. 2014), Australia (Pattiaratchi and Wijeratne 2014), and New Zealand (Goring 2005).

There have been multiple instances of large, destructive meteotsunamis estimated at over $4 \mathrm{~m}$ in the Balearic Sea, Spain (Jansá et al. 2007; Rabinovich and Monserrat 1996), and at Nagasaki Bay, Japan (Hibiya and Kajiura 1982), and $6 \mathrm{~m}$ in Croatia on the Adriatic (Vučetić et al. 2009). In the United States, there have been meteotsunami waves estimated to be over $3 \mathrm{~m}$ on the Florida Gulf Coast (Paxton and Sobien 1998) and at Daytona Beach on the Florida Atlantic Coast (Churchill et al. 1995; Sallenger et al. 1995), and $4 \mathrm{~m}$ in Boothbay Harbor on the coast of Maine (Vilibić et al. 2014b). Many of these cases included substantial human casualties or damages to boats and infrastructure.

\section{FINDING METEOTSUNAMIS IN WATER-} LEVEL OBSERVATIONS. Meteotsunamis have certain characteristics that must be considered for identification in a water-level record. There must be significant wave energy within the tsunami frequency band and an observed atmospheric forcing mechanism like sharp gradients in atmospheric pressure or wind (Monserrat et al. 2006). Further, meteotsunamis are often only considered if they exceed some minimum peak-to-trough wave height, typically anywhere from 0.1 to $0.4 \mathrm{~m}$ (e.g., Monserrat et al. 2006; Olabarrieta et al. 2017; Pasquet et al. 2013). Because of their generation and propagation characteristics, substantial meteotsunamis occurring on the U.S. East Coast typically have a spatial extent $>100 \mathrm{~km}$ (Pasquet et al. 2013).
Here a meteotsunami is defined by wave-frequency characteristics and potential meteorological forcing. Following similar approaches used to identify both seismic tsunamis (Heidarzadeh and Satake 2013; Rabinovich and Thomson 2007) and meteotsunamis (Bechle et al. 2016; Monserrat et al. 2006; Olabarrieta et al. 2017; Pattiaratchi and Wijeratne 2014) in tide gauge records, a meteotsunami is detected when the following criteria are met:

- Wavelet energy in the tsunami frequency band (12-120 $\mathrm{min}$ ) is greater than six standard deviations from the mean tsunami-band wavelet energy.

- The maximum peak-to-trough wave height $>0.20 \mathrm{~m}$.

- The event is observed by a minimum of two tide gauges within the same geographic region (regions indicated in the supplement online at https://doi .org/I0.II75/BAMS-D-18-0206.2).

- An air pressure perturbation exceeding $0.9 \mathrm{mb}$ per 6-min interval or a wind speed exceeding $10 \mathrm{~m} \mathrm{~s}^{-1}$ is observed in the same geographic region within $12 \mathrm{~h}$ prior to the observed wave.

These criteria were tested through prototyping with known meteotsunami events and are used in the automated detection approach described in detail below. The primary differences between this approach and other identification schemes is that here the wavelet energy is the initial and primary criterion to identify an event. The wavelet energy is used to determine that some significant amount of energy exists within the tsunami-frequency band, and then the wave height threshold ensures that the result of this energy is a wave that reaches some physically meaningful height. The wavelet approach improves efficiency and better enables automation by ensuring that the oscillations identified are in the appropriate frequency range prior to further analysis. This automation was a critical component of completing the climatology, as a more manual review of a total of over 1,500 years of 6-min water-level data would be time prohibitive.

Water-level observations. Water-level observations were collected from 125 NOAA and NOAA partner tide gauges along the U.S. East Coast, in the Caribbean, and at Bermuda (Fig. 2). These gauges have all collected at least 1 year of 6-min water-level data from 1996 through 2017, with 70 of the stations collecting at least 10 years of data and 43 stations collecting at least 20 years of data. All 6-min observations included in the analyses undergo both automated and manual quality control to ensure 
data quality (as in Gill and Schultz 2000). In addition to 6-min water-level observations, there are 1-min water-level observations at 81 gauges collected and processed since 2007. Both 6- and 1-min observations are collected via the same sensor at each gauge, which for this time period of observations is usually an acoustic sensor with a polyvinyl chloride (PVC) protective well (Edwing 1991), though vented pressure sensors and microwave radar sensors are also used (Heitsenrether and Davis 2011). Since meteotsunami wave periods are relatively long oscillations, the observed wave signal is not expected to be influenced by the type of sensor used or the acoustic sensor's protective well, which has been shown to primarily filter high-frequency wind waves (Park et al. 2014). Although 1-min observations are primarily collected and utilized to observe seismic tsunamis (Dunbar et al. 2017, 2008), the much shorter time series and substantial gaps prevent using these observations for

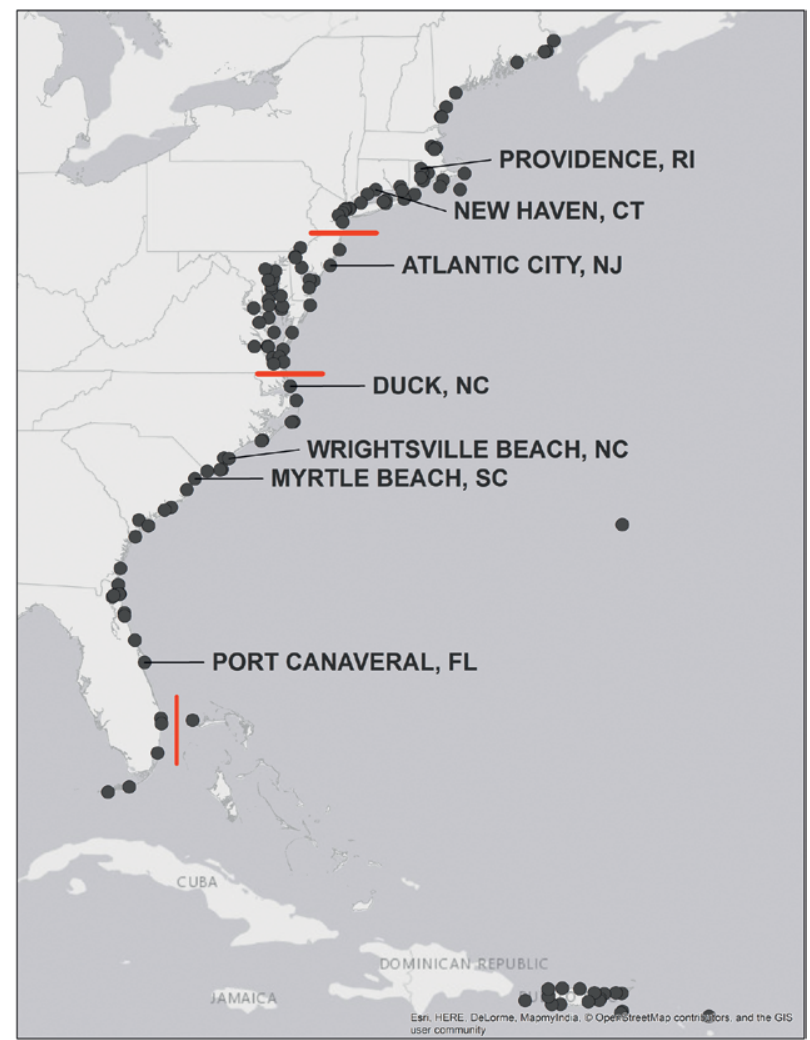

FIG. 2. The locations of the 125 NOAA and NOAA partner tide gauges with at least I yr of water-level observations from 1996 to 2017, which are utilized for the meteotsunami climatology. Seven of the stations that observe frequent events and are discussed in the text are labeled. The red lines indicate the breakdown between geographic regions from the Northeast, midAtlantic, Southeast, and Caribbean. The corresponding list of stations can be found in the supplement. a climatology. Instead, 1-min data are used to assess the potential biases introduced by using the lowerfrequency 6-min data for peak-to-trough wave height and wave period estimates (see sidebar).

Identifying the meteotsunami signal. To isolate the meteotsunami signal the tide is removed or "detided" from the 6-min water-level time series at each gauge by subtracting NOAA tide predictions (Parker 2007), and then the time series is filtered using a low-pass Chebyshev type-2 digital filter with a stop-band period of $4 \mathrm{~h}$, a passband period of $6 \mathrm{~h}$, and cutoff of $5.7 \mathrm{~h}$ [following the filter design process as described in Thomson and Emery (2014)]. High-pass-filtered water-level time series are calculated by subtracting the low-pass time series from the original. This approach is consistent with previous meteotsunami research (Olabarrieta et al. 2017; Pasquet et al. 2013; and others), and ensures that most tidal energy is removed without modifying oscillations close to the 2-h maximum expected meteotsunami frequency. Since the wavelet analysis identifies the meteotsunami signal, the filtered time series is only used for peak-to-trough wave height calculation.

A wavelet analysis is performed on the 6-min water-level time series in 1-yr segments as the first step to detect a potential event. A continuous wavelet transform using the Morlet wavelet (Kumar and Foufoula-Georgiou 1997; Torrence and Compo 1998) is used to identify time-varying peaks of wavelet energy in the tsunami-frequency band. Though similar to traditional spectral analysis, wavelets excel at identifying discontinuities or time-varying events in time series data and thus are ideal for tsunami (Heidarzadeh and Satake 2013) or meteotsunami (Pattiaratchi and Wijeratne 2014) identification. Potential events are identified when a 6-min peak in wavelet energy in the tsunami band exceeds six standard deviations from the mean of the 1-yr segment at each gauge. This threshold is similar to previous studies (Monserrat et al. 2006; Olabarrieta et al. 2017), was found to be conservative, and was chosen based on prototyping with known meteotsunami events. All wavelet energies exceeding this threshold with \pm 24 -h groupings are identified as the same potential event.

Once a potential event is detected, the peak wave frequency is determined from the wavelet transform and the largest peak-to-trough wave height is calculated from the high-pass-filtered water-level time series (Fig. 3). To avoid potentially measuring seiche or surge heights that were not filtered out (i.e., oscillations with peak period $>\sim 120 \mathrm{~min}$ ), the peak-to-trough wave height was calculated as the difference between 
maximum concurrent peak and trough elevations constrained by the peak observed frequency (similar to Dunbar et al. 2017). An event is considered only when wave height $>0.20 \mathrm{~m}$ for at least two tide gauges within the same geographic region (regions are listed in the supplement). The wave height threshold was chosen through prototyping with known meteotsunami events and was found to be the smallest threshold to reliably identify events and avoid false positives. As discussed, this threshold is similar to wave height thresholds used in previous studies (Monserrat et al. 2006; Olabarrieta et al. 2017; Pasquet et al. 2013). The multiple gauge criteria can be established and used due to the dense spatial coverage of tide gauges along the East Coast and is essential to minimize false positives in an automated detection approach.

A meteorological assessment is made after this stage of event identification to ensure that the event is meteorologically forced. Similar to the method used in the Great Lakes (Bechle et al. 2016), the assessment seeks to identify either a $0.9 \mathrm{mb}$ per 6 -min air pressure perturbation or wind speed exceeding $10 \mathrm{~m} \mathrm{~s}^{-1}$ within $12 \mathrm{~h}$ prior to the observed wave. These thresholds were derived from the lower bounds of perturbations observed to lead to meteotsunamis in the literature (Linares et al. 2016; Šepić et al. 2012). A 12-h threshold was used because in many cases the observed maximum wave height at some gauges occurred hours following the measurement of the meteorological disturbance. For example, in the 13 June 2013 case (Fig. 1) the maximum wave height was observed at Cape Hatteras, North Carolina, about $10 \mathrm{~h}$ following the initial disturbance measured at Lewes, Delaware. Since 2004, both air pressure and wind speed are collected at most NOAA tide gauges, and the automated approach relies on these observations over the region(s) where the event occurred. In the limited cases where events did not meet the meteorological threshold, a manual assessment of additional wind and pressure data was performed. Out of the 355 potential meteotsunami events since 2004 , only four events failed the meteorological check. The 6-min air pressure data are not available at NOAA tide gauges prior to 2004, and are limited in availability at other sources as well. This data limitation results in a larger number (54 out of 193) of potential events that fail the meteorological check from 1996 to 2003. These events are also manually checked for data inconsistencies and against known seismic tsunamis and so nonmeteorological forcing is highly unlikely. The primary purpose of the meteorological check is to provide additional quality control and to ease automation. Given the severe atmospheric data

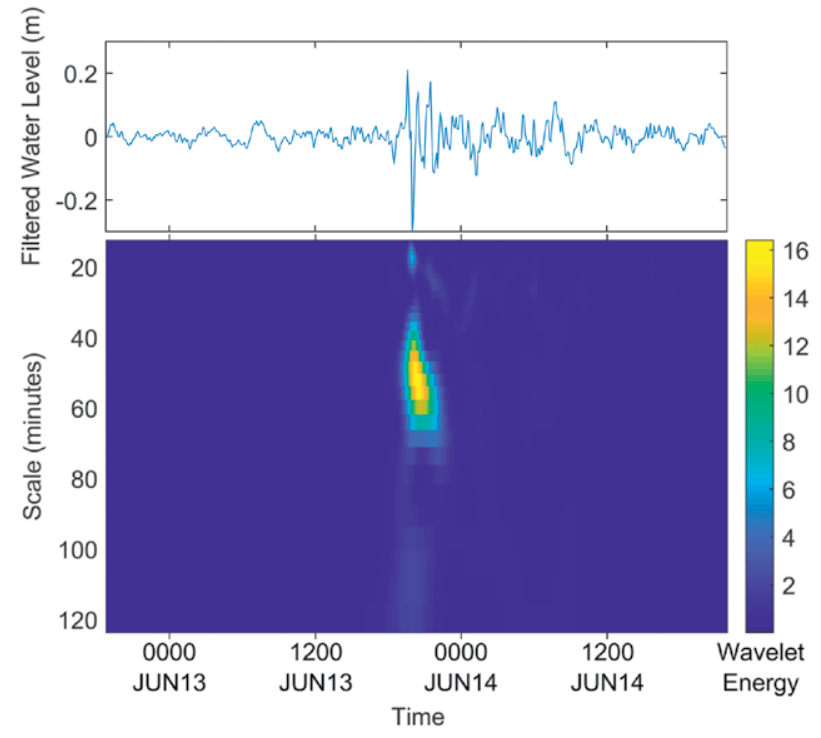

Fig. 3. (bottom) Example of a wavelet spectrogram and (top) filtered high-frequency water-level time series from Woods Hole, MA, during the 13 Jun 2013 meteotsunami. Contour units are wavelet energy $\times 10^{-3}$.

\section{COMPARISON WITH I-MIN WATER-} LEVELL OBSERVATIONS

$T^{\mathrm{T}}$ he majority of previous meteotsunami studies have relied on 6-min water-level observations; however, I-min water-level observations have been used in some cases (Pasquet et al. 2013). Using I-min data would be ideal, as the high-frequency oscillations and sometimes extreme peak water level can be either aliased or underestimated when using the 6-min observations. However, quality-controlled I-min observations (Dunbar et al. 2008) are not available at any locations until 2007 and even quality-controlled time series have significant data gaps making filtering and wavelet analyses impractical.

Meteotsunami wave height and period calculated from the 6-min and available I-min water-level data were compared to estimate potential bias or error. A total of 219 gauge-event pairs (i.e., multiple gauges observe each event) were compared. The I-min time series were processed through the same algorithm as the 6-min time series when events were detected and when the I-min data record was complete. Wave height estimates from 6-min observations are on average biased low by $3.8 \mathrm{~cm}$, with a standard error of $5 \mathrm{~cm}$. Peak wave period demonstrates a positive bias of $1.7 \mathrm{~min}$ and standard error of $11.9 \mathrm{~min}$. The I-min peak wave period was below 12 min for only II out of the 219 pairs, indicating that aliasing is generally not a concern. This assessment demonstrates that 6-min observations are generally sufficient to accurately observe meteotsunami events, though wave height estimates will slightly underestimate the true wave height. 
limitations prior to 2004 and given that only $1 \%$ of cases failed the meteorological check after 2004, it was determined that the more unbiased approach was to retain the 54 events that failed the meteorological check prior to 2004 .

Last, a rigorous manual quality assessment of all 580 potential identified events was performed. The assessment resulted in 32 events completely removed and 24 events partially removed (often due to questionable data spikes at the Fort Pulaski, Georgia, gauge), leaving a total of 548 meteotsunami events observed from 1996 to 2017. An event capturing the December 2004 Sumatra seismic tsunami (Rabinovich et al. 2006) was also removed, though it occurred concurrently with a meteotsunami
(Thomson et al. 2007) as the resultant meteotsunami wave height could not be adequately resolved by this approach.

\section{U.S. EAST COAST METEOTSUNAMI \\ CLIMATOLOGY. A total of 548 meteotsunami} events were detected on the U.S. East Coast from 1996 to 2017, for an average of about 25 events per year. On average, 3.8 gauges observed each event, for a total of 2,065 event-gauge pairs. The majority of events were measured at only a few gauges and $84 \%$ of all events were measured at five or fewer gauges. There were several widespread events including 26 cases of a single meteotsunami event observed at 10 or more gauges. Twice a meteotsunami was observed

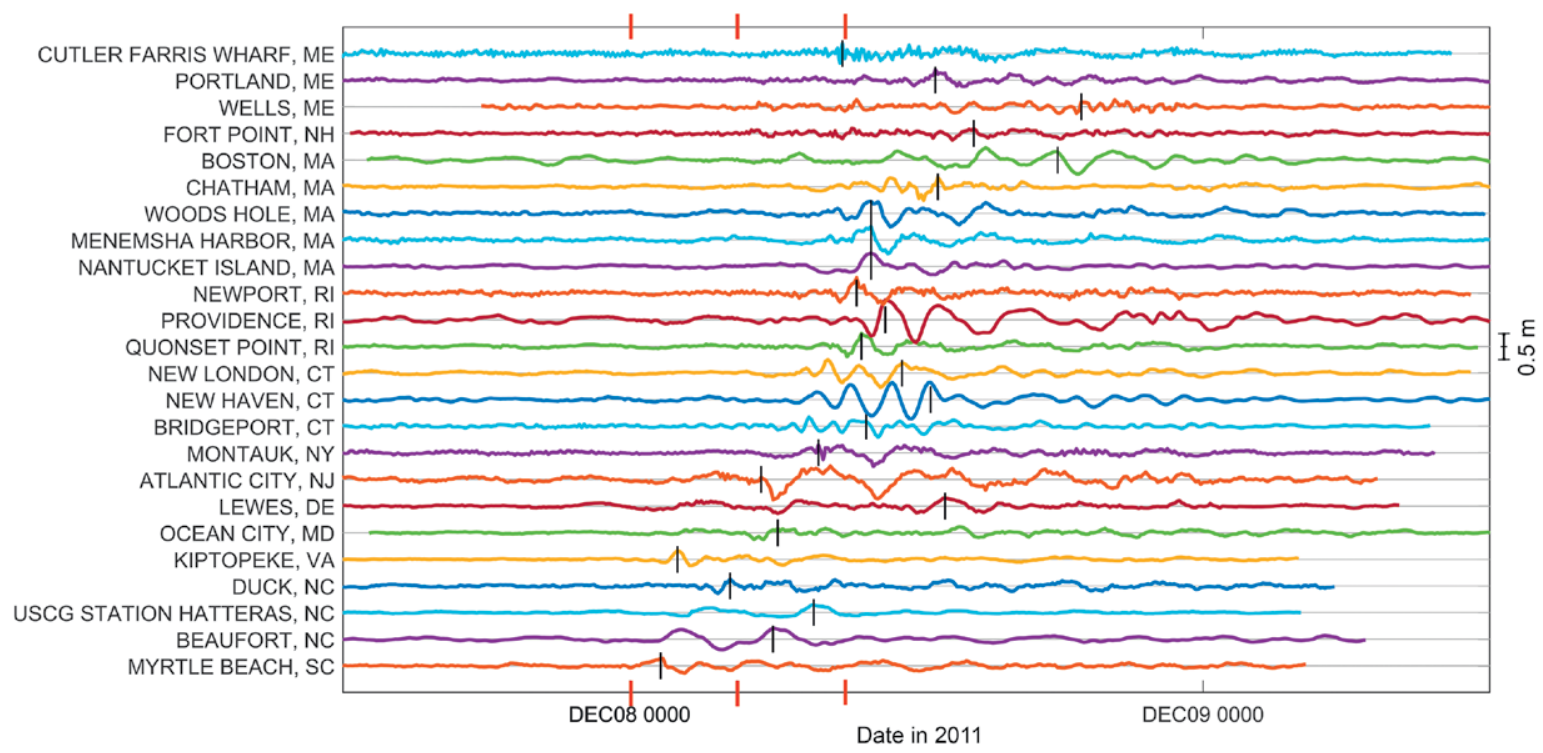

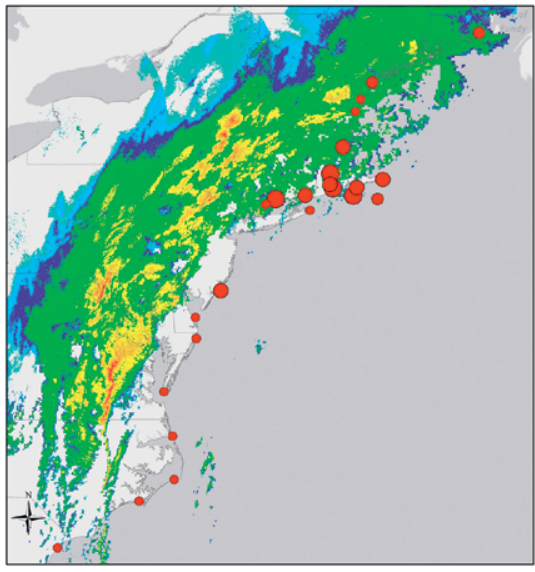

0000 UTC

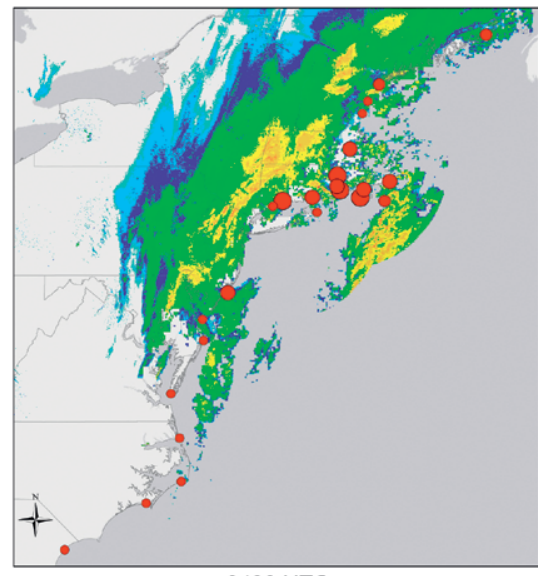

0430 UTC

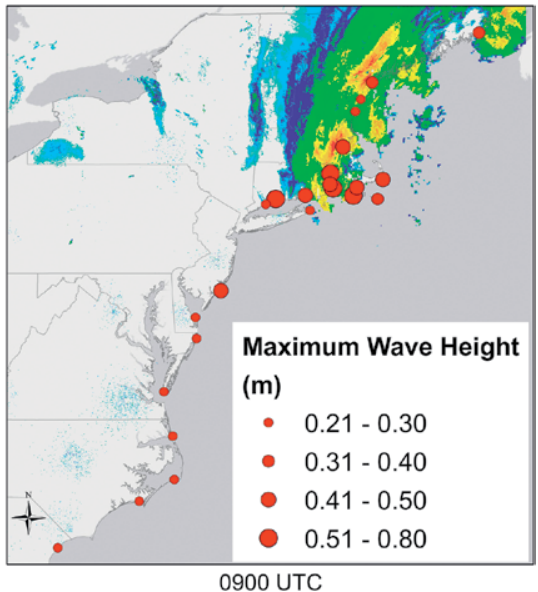

Fig. 4. (top) The filtered high-frequency water level and (bottom) the radar imagery and maximum observed wave height for the $8 \mathrm{Dec} 20 \mathrm{II}$ meteotsunami. In the top panel, stations are listed generally north to south sorted by state, times of maximum peak-to-trough wave height are identified by the vertical black lines, and spacing between axes indicates a peak-to-trough wave height of $0.5 \mathrm{~m}$. Vertical red lines indicate the times of the radar imagery on $8 \mathrm{Dec}$. In the bottom panel, the maximum wave heights are shown by the size of the markers. A total of $\mathbf{2 4}$ gauges observed the event with a maximum wave height of $0.80 \mathrm{~m}$ at Providence, $\mathbf{R I}$. 
at 24 gauges, including the event on 8 December 2011 (Fig. 4).

The distribution of peak-to-trough wave heights suggests that most meteotsunamis that occur on the East Coast are relatively small (Fig. 5). Roughly 73\% of all events were under $0.30 \mathrm{~m}$ in height, and about $91 \%$ were under $0.40 \mathrm{~m}$. There were 30 instances when a gauge measured a wave height exceeding $0.60 \mathrm{~m}$, with three of these instances exceeding $1 \mathrm{~m}$. Peak wave period was somewhat more evenly distributed across the tsunami-frequency band with a slight skew toward longer frequencies $(66 \%>1 \mathrm{~h})$. Though there is not a strong correlation between wave height and wave period, the largest waves were generally relatively long waves. None of the events exceeding 0.6-m wave height had a peak period under $40 \mathrm{~min}$.

Meteotsunamis occur along most of the East Coast, from northern Maine to Key West, Florida (Fig. 6 and supplement), but with some notable variations in event magnitude and frequency. Myrtle Beach, South Carolina, and Duck, North Carolina, observed the greatest number of events with $148\left(7.2 \mathrm{yr}^{-1}\right)$ and $130\left(6.0 \mathrm{yr}^{-1}\right)$, respectively, while Wrightsville Beach, North Carolina $\left(8.7 \mathrm{yr}^{-1}\right)$, and Cape Hatteras $\left(8.9 \mathrm{yr}^{-1}\right)$ had the highest averages per year for any station with at least 5 years of data. Events were also common in Long Island Sound, particularly New Haven, Connecticut, and Providence, Rhode Island, which both average 5.4 meteotsunamis each year. Atlantic City, New Jersey $\left(5.6 \mathrm{yr}^{-1}\right)$, observed frequent events, at least in part due to its exposed, open coast location. Last, meteotsunamis were fairly common along the northern Florida coast, especially at both St. Augustine $\left(4.2 \mathrm{yr}^{-1}\right)$ and Port Canaveral $\left(3.3 \mathrm{yr}^{-1}\right)$.

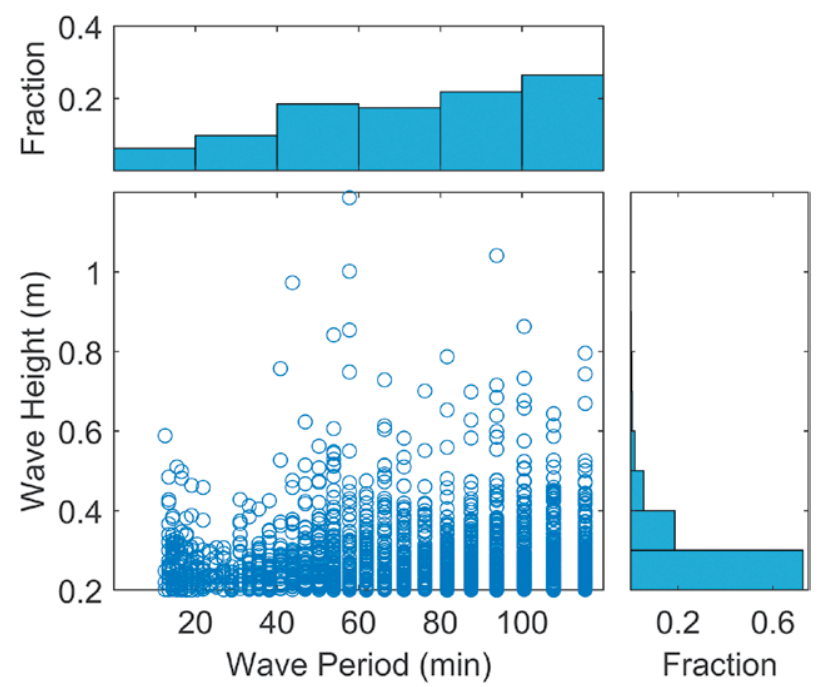

Fig. 5. (bottom left) Scatterplot of peak wave period to peak-to-trough wave height of all identified station-event pairs, and thus one point is shown for each station per event. (right) The binned distributions of wave height and (top left) peak period are shown.
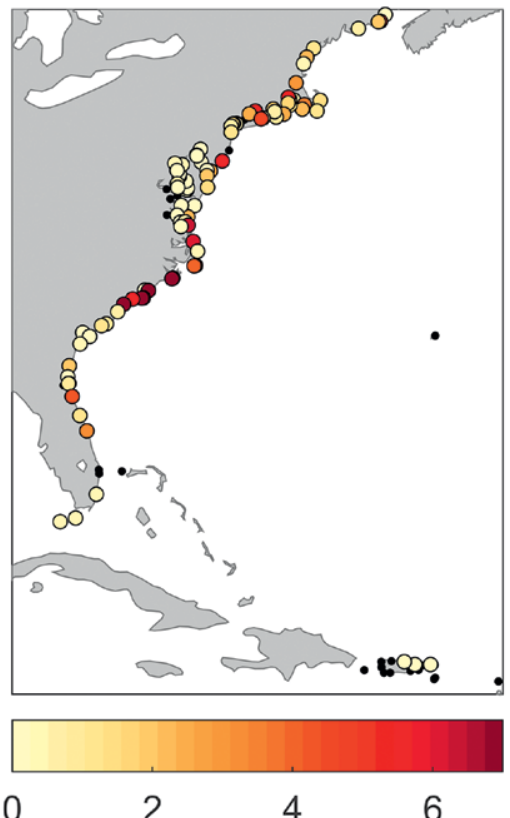

Events per year
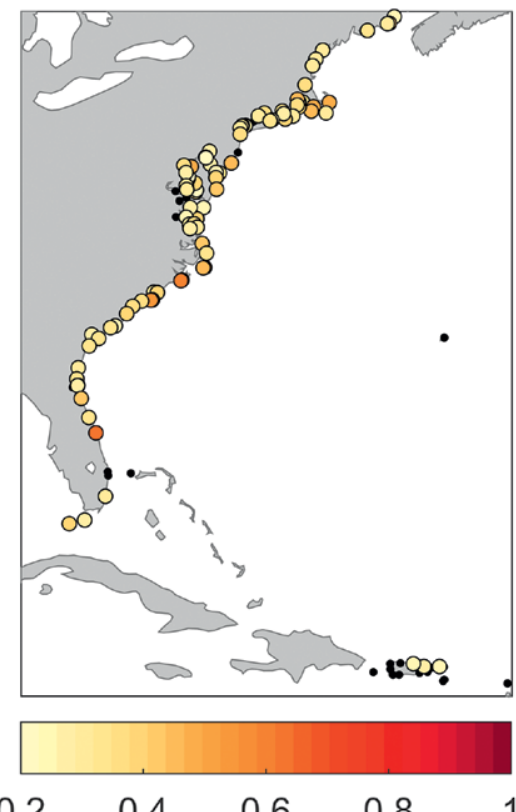

$\begin{array}{lllll}0.2 & 0.4 & 0.6 & 0.8 & 1\end{array}$

Top decile observed height $(\mathrm{m})$
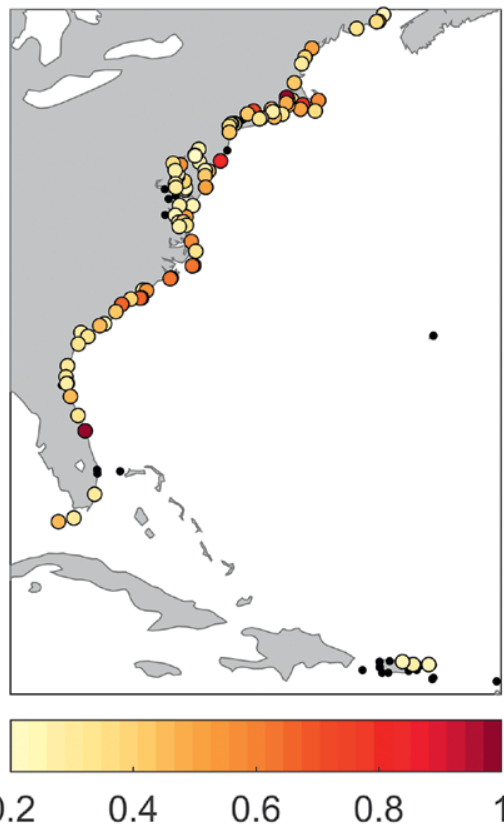

Maximum observed height $(\mathrm{m})$

Fig. 6. (left) The average number of events observed per year at each gauge location and (middle) the top decile and (right) maximum peak-to-trough wave height observed at each gauge location. Small black dots indicate no events observed at those locations. 
The largest meteotsunamis tend to occur in places that observed frequent events (Fig. 6 and supplement). Atlantic City, Cape Hatteras, Providence, and Port Canaveral all observed events exceeding a wave height of $0.8 \mathrm{~m}$. The largest meteotsunamis recorded over the 22-yr data record include a 1.04-m event at Providence during a winter storm on 9 December 2005 and a 1.19-m event at Port Canaveral on 19 June 1996 (Fig. 7). Both Providence (five) and Port Canaveral (eight) have multiple large events exceeding a wave height of $0.6 \mathrm{~m}$.

Temporal variability in meteotsunami occurrence is apparent over a range of time scales. Annually, the number of observed events ranges from 16 to 33 depending on the year (Fig. 8). In addition to the total number of events, a meteotsunami anomaly was calculated to account for differences in the number and locations of gauges active during any one year. The meteotsunami anomaly is the difference between the average observed meteotsunami events per station for a given year and the average expected number of meteotsunami events per station for a given year. The anomaly largely tracks the total events so network bias does not appear to be substantial.
There are summer and winter seasonal peaks in meteotsunami occurrence. The greatest monthly frequencies are in June and July with a second peak in occurrence from December through March (Fig. 8). Meteotsunamis tend to be less common in May and from August to November. However, the meteotsunamis that occur from August to October are occasionally coincident in time with tropical cyclones, for example, during Hurricane Irma in 2017 (Fig. 9). Tropical cyclones were associated with 19 out of the 92 meteotsunamis that were observed during these months. The monthly distribution of only the largest $10 \%$ of meteotsunami events further elucidates the seasonal cycle, with larger events more evident in the winter and in September (Fig. 8, bottom). The time of day when meteotsunamis are most likely to occur is also seasonally driven. During the summer months, events are most common in the afternoon and early evening (e.g., $77 \%$ of all events in July), while the winter distribution is much more even throughout the day ( $57 \%$ occur in the afternoon and early evening in January).

Seasonal variability in meteotsunami occurrence is also apparent when comparing different regions
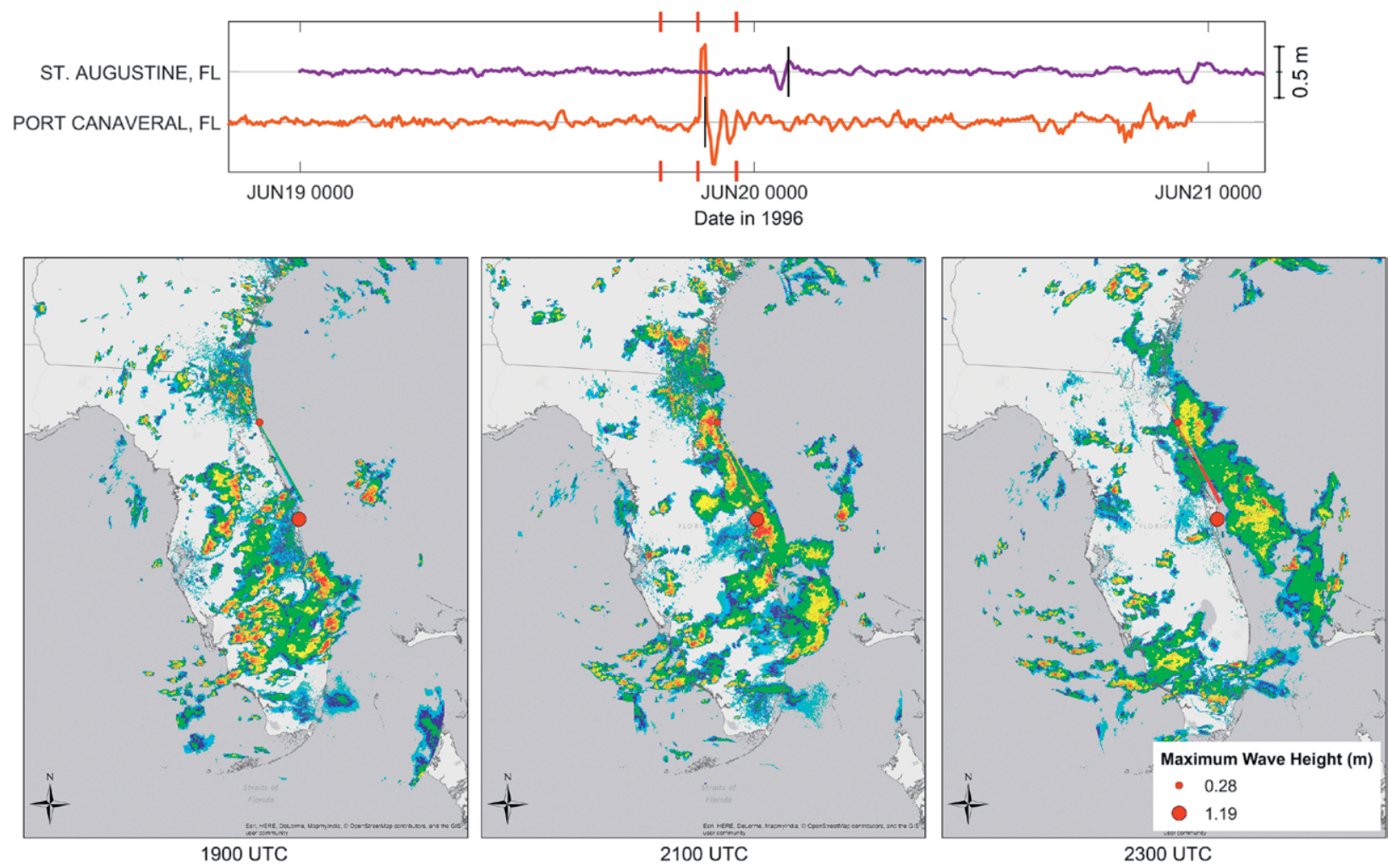

Fig. 7. (top) The filtered high-frequency water level and (bottom) the radar imagery and maximum observed wave height for the 19 Jun 1996 meteotsunami. In the top panel, stations are listed north to south, times of maximum peak-to-trough wave height are identified by the vertical black lines, and spacing between axes indicates a peak-to-trough wave height of $0.5 \mathrm{~m}$. Vertical red lines indicate the times of the radar imagery on $19 \mathrm{Jun}$. In the bottom panel, the maximum wave heights are shown by the size of the markers. Two gauges observed the event with a maximum wave height of $1.19 \mathrm{~m}$ at Port Canaveral, FL, being the largest event recorded from I996 to 2017. 
along the East Coast (Fig. 10). The Northeast and portions of the Southeast (North and South Carolina) tend to be active in the winter months (DecemberFebruary), while the mid-Atlantic gauges, with the exception of Atlantic City, observe relatively few winter events. This suggests that wintertime meteotsunamis tend to not impact the Chesapeake and Delaware Bays (where many of the mid-Atlantic gauges are located), potentially because the bays are more protected from coastal winter storms and nor'easters. In the summer months (June-August), however, the mid-Atlantic, including the Chesapeake and Delaware Bays, and portions of the Southeast see a relatively large number of meteotsunamis and the Northeast observes

FIG. 8. (top) Shown are the total number of meteotsunami events each year (left $y$ axis) and the normalized meteotsunami anomaly (right $y$ axis). (middle) The average number of meteotsunami events each month broken down by time of day and (bottom) the monthly average of only the events with the top $10 \%$ of maximum wave heights (largest 55 events). relatively fewer. In particular, the coastline north of Woods Hole, Massachusetts, through Maine has almost no summertime events, despite being relatively active at other times of the year.
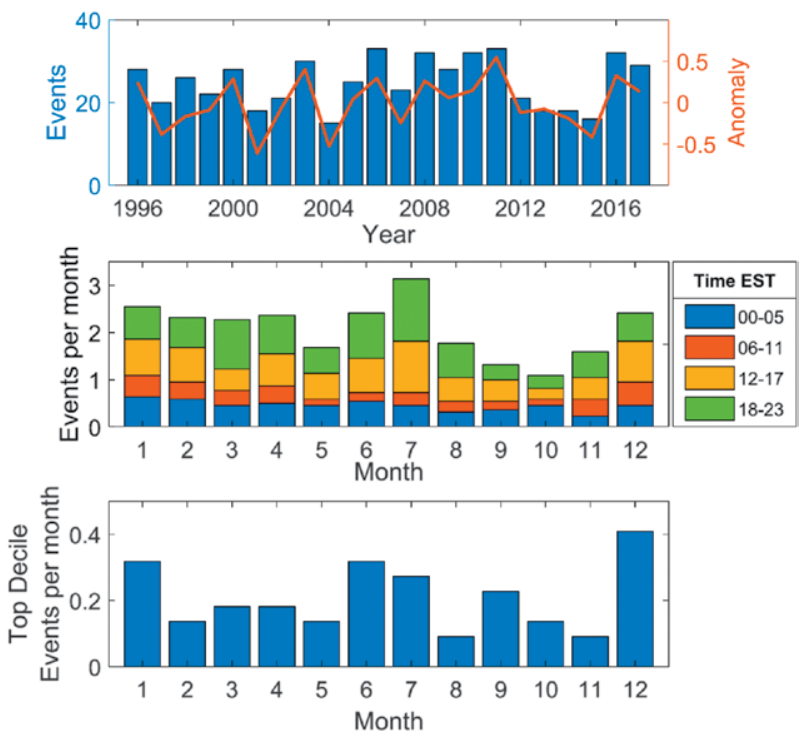
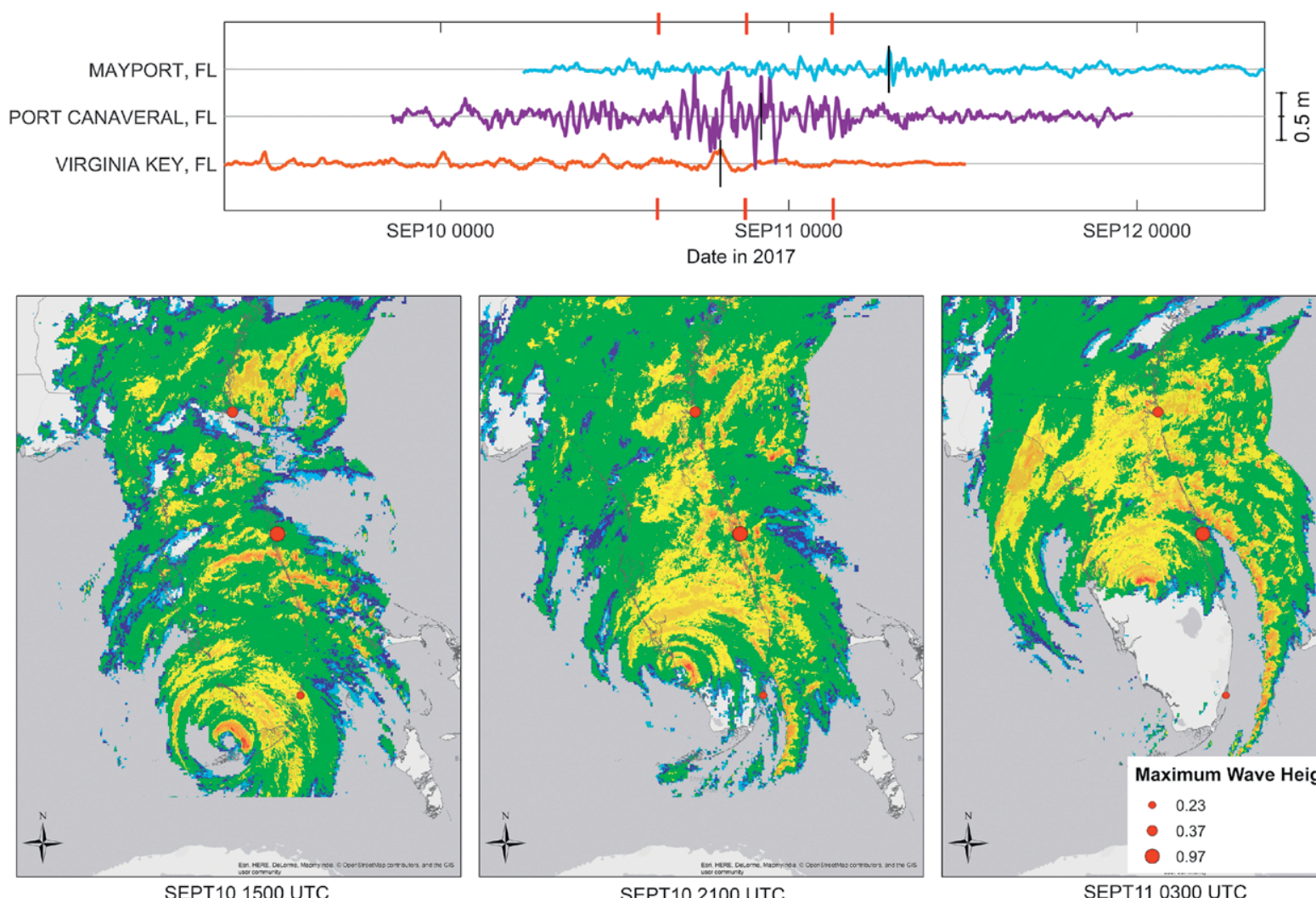

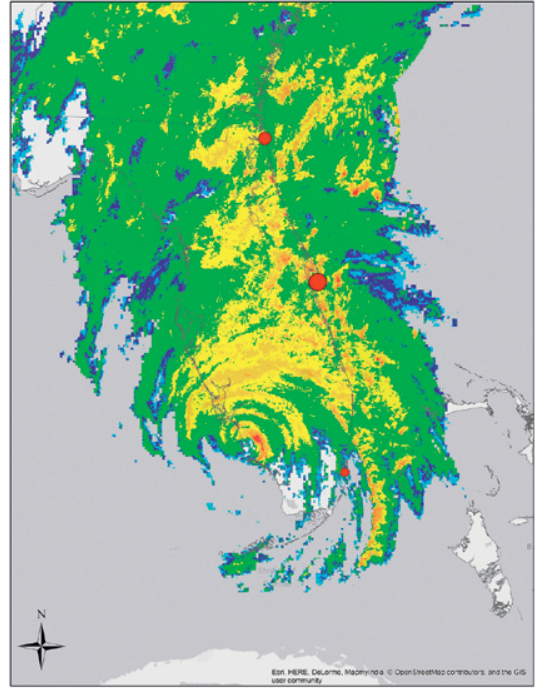

SEPT10 2100 UTC

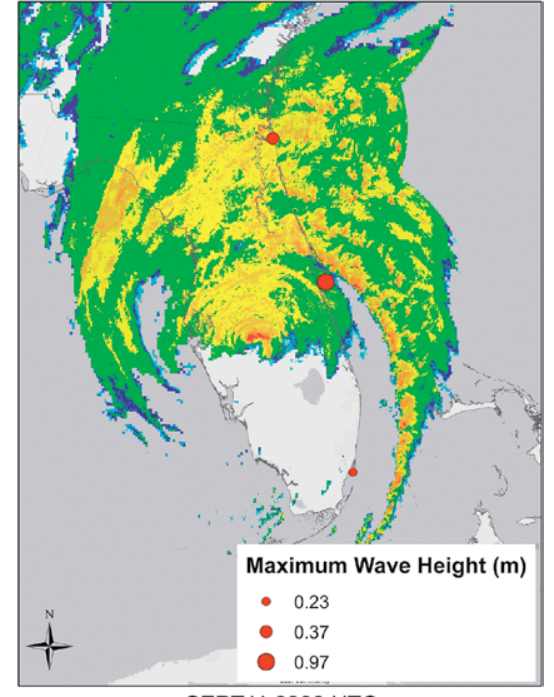

SEPT11 0300 UTC

Fig. 9. (top) The filtered high-frequency water level and (bottom) the radar imagery and maximum observed wave height for the 10-II Sep 2017 meteotsunami. In the top panel, stations are listed north to south, times of maximum peak-to-trough wave height are identified by the vertical black lines, and spacing between axes indicates a peak-to-trough wave height of $0.5 \mathrm{~m}$. Vertical red lines indicate the times of the radar imagery. In the bottom panel, the maximum wave heights are shown by the size of the markers. The event was associated with Hurricane Irma and reached a maximum wave height of $0.97 \mathrm{~m}$ at Port Canaveral, FL. 
In addition to regional characteristics, there are a number of gauges that observe frequent events regardless of season. In particular Atlantic City, Duck, and Myrtle Beach tend to observe similarly large numbers of events throughout much of the year. These gauges are some of the most exposed coastal gauges on the East Coast, and are on long straight coastlines with relatively little topographic variability. Thus, they tend to be exposed to events regardless of season or mechanism.

Return period estimates are made for some of the more active locations with longer time series. A generalized Pareto distribution (GPD; Coles 2001) is typically utilized to fit peaks over threshold data, is

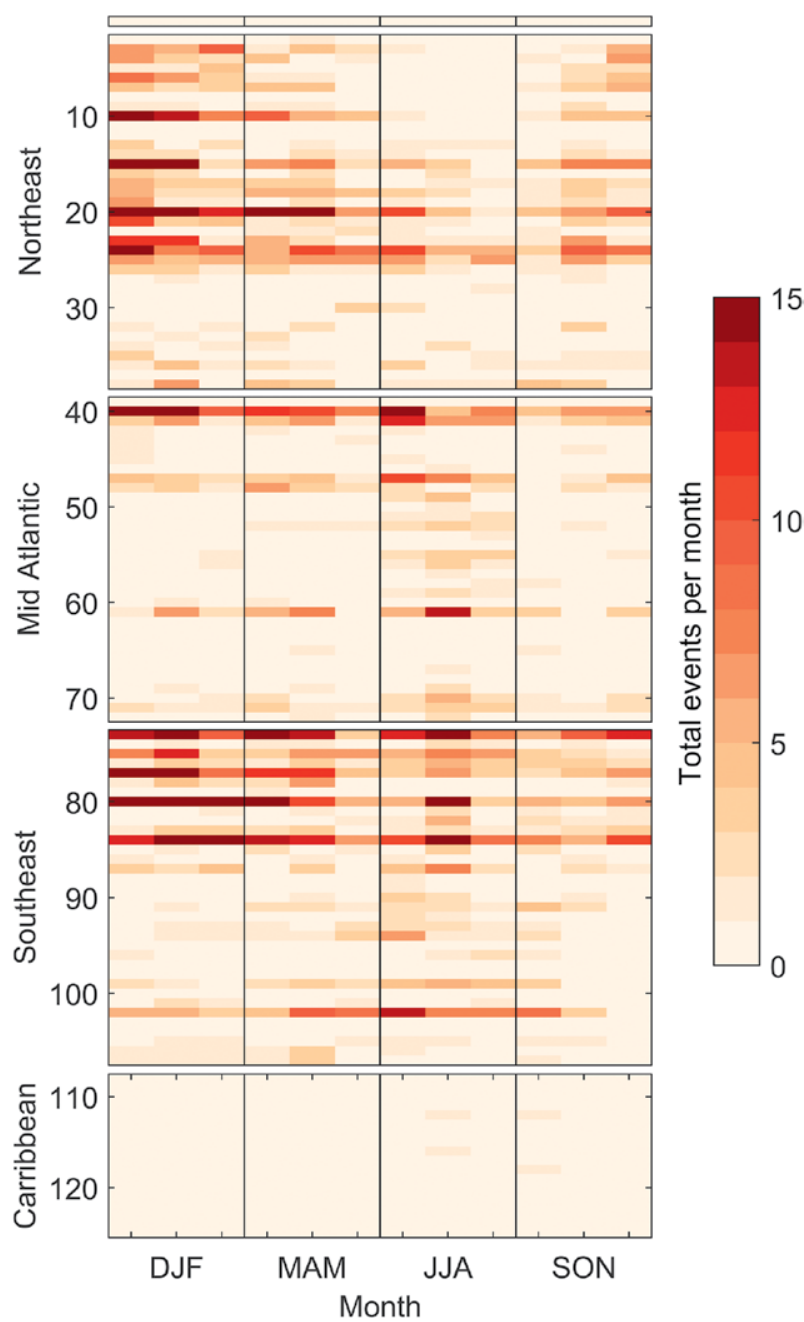

FIG. 10. The monthly distribution of all observed meteotsunami events across all stations partitioned by season. Note that the total number of events per month exceeds 15 for some gauges. The locations of the breaks between regions are noted on the tide gauge map (Fig. 2). The numbers on the $y$ axis correspond to the row numbers for stations in the supplement and the top (unlabeled) region is Bermuda. used in similar studies (Bechle et al. 2016; Geist et al. 2014), and was found to be the optimal fit for these data. A GPD fit was made for 29 gauges with at least 10 years of data and 15 observed meteotsunami events with $95 \%$ confidence limits calculated via a bootstrap approach (Fig. 11; Caires 2007; Coles and Simiu 2003). Here, return periods of 1,5 , and 50 years are calculated (Fig. 12 and supplement). The 50 -yr return period was selected to provide some indication of extreme events; however, it is important to note the relatively large confidence bounds due to the 22 -yr observation record.

The 1-yr events are typically small regardless of location and range, with wave heights of around 0.2-0.4 m. Only two locations, Port Canaveral and Providence, have a height for the 1-yr return period exceeding $0.4 \mathrm{~m}$. Both of those locations also have the largest 5 -yr return period heights, with Providence exceeding $0.60 \mathrm{~m}$ and Port Canaveral exceeding $0.70 \mathrm{~m}$. Atlantic City also has a fairly substantial 5-yr return period, reaching a height of $0.57 \mathrm{~m}$. A majority of gauges ( 22 out of 29 ) have 5 -yr return periods between 0.30 and $0.50 \mathrm{~m}$. The $50-y r$ return periods suggest fairly extreme events are possible at some locations. In particular, Port Canaveral (1.26 m), Woods Hole $(1.12 \mathrm{~m})$, and Providence $(0.97 \mathrm{~m})$ have high wave height estimates, consistent with the largest observed events over the past 22 years. In all, seven gauges have $50-y r$ return period heights exceeding $0.60 \mathrm{~m}$.

DISCUSSION AND CONCLUSIONS. The climatology suggests that meteotsunamis frequently

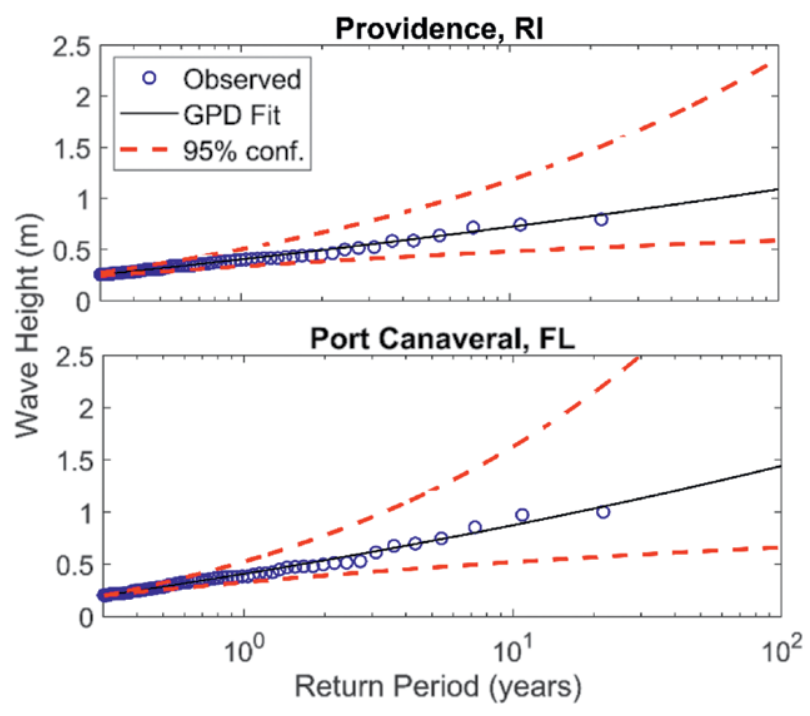

FIG. II. Example of GPD fit for all observed meteotsunami events with the $95 \%$ confidence limits for Providence, RI, and Port Canaveral, FL. Note the large confidence limits for long-return-period events. 
occur along much of the U.S. East Coast. Though more numerous in the summer and winter months, they can occur during all times of the year and from a range of underlying meteorological conditions. Similar to what has been observed in the Great Lakes and Gulf Coast (Bechle et al. 2016; Olabarrieta et al. 2017), the vast majority of observed meteotsunamis are quite small ( $91 \%$ of the total 2,065 gauge-event pairs have wave heights of less than $0.40 \mathrm{~m}$ ). This is an important distinction to make when communicating about meteotsunamis to the general public, as many people associate the term tsunami with a large or even catastrophic wave event. Assuming a wave height exceeding $0.60 \mathrm{~m}$ is a potentially impactful event (the June 2013 event reached $0.57 \mathrm{~m}$; Fig. 1), these occur much less frequently, only about one time per year on average. The likelihood of observing an impactful event at most gauge locations is fairly low, as the wave height for the 5 -yr return period exceeds $0.60 \mathrm{~m}$ at only two locations (Providence and Port Canaveral) and the 50-yr return period exceeds $0.60 \mathrm{~m}$ at only seven locations.

Some important location characteristics were observed in the number of events, the magnitude of events, and the seasonality of events. One of the underlying factors that dictates whether locations observe frequent events is whether the tide gauge is located on the exposed open coast or is in a more protected inland location. The gauges in Atlantic
City, Duck, Wrightsville Beach, and Myrtle Beach are all located on exposed, oceanic piers and all observed over 100 total events $\left(>5 \mathrm{yr}^{-1}\right)$. Meanwhile, locations that are up-estuary (especially narrow, riverine estuaries) not surprisingly observed few or no events. For example, Wilmington, North Carolina, is less than $20 \mathrm{~km}$ away from the gauge at Wrightsville Beach, but is located within the Cape Fear River and thus only observed one event for nearly 22 years of observations.

The exception to this rule are places in more exposed estuarine locations, for which the topography, shape, and orientation of the estuary favors amplifying the meteotsunami signal. The best examples of this are Providence, New Haven, and Port Canaveral. The Providence gauge is located on the Providence River, nearly $50 \mathrm{~km}$ up-estuary at the head of Narragansett Bay, yet it observed over 100 events, including five events with a wave height over $0.60 \mathrm{~m}$. Oscillations in the tsunami frequency band appear to be amplified at this location, and are often coincident with slightly lower-frequency oscillations (periods of 3-4 h). The New Haven gauge is on an exposed pier only $5 \mathrm{~km}$ up New Haven Harbor on the northern side of Long Island Sound. Therefore, the gauge is fairly exposed to impacts from the sound while also potentially further amplifying meteotsunami signals due to the shape of the harbor. This location observed 98 events
1 year
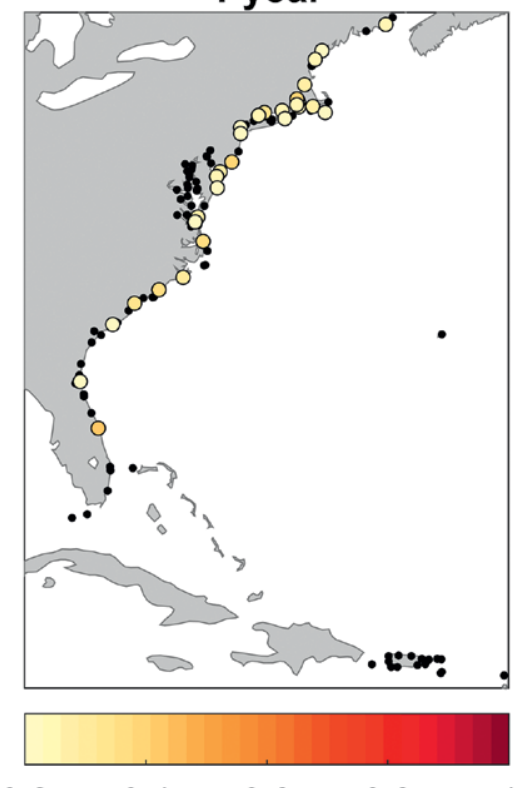

$\begin{array}{lllll}0.2 & 0.4 & 0.6 & 0.8 & 1\end{array}$
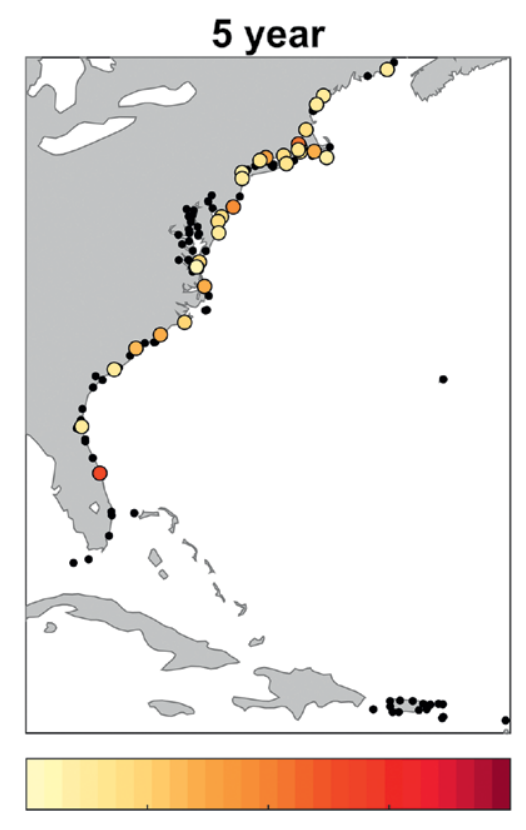

$\begin{array}{lll}0.4 & 0.6 & 0.8\end{array}$

Wave Height (m)

FIG. I2. The GPD estimated (left) I-, (middle) 5-, and (right) 50-yr return period wave heights for 27 locations with at least 10 years of data and 15 observed meteotsunami events. 
over about 18 years (more than five events per year). Last, the Port Canaveral gauge is less than $1 \mathrm{~km}$ inside the Canaveral Barge Canal, and is fairly exposed to oceanic forcing. The Port Canaveral gauge observed slightly fewer events (about three per year on average); however, it observed eight events over $0.60 \mathrm{~m}$, including the largest meteotsunami observed for all gauges at a wave height of $1.19 \mathrm{~m}$ (Fig. 7). The shape of the canal is apparently such that oscillations in the tsunami frequency band are significantly amplified.

There are location-specific seasonal dependencies on meteotsunami occurrence that correspond well to U.S. East Coast storm occurrence. There is one seasonal peak in meteotsunami occurrence in June and July (Fig. 8), especially for the mid-Atlantic and southeast regions (Fig. 10). This corresponds well to the frequencies of severe thunderstorms, which peak in June and July for much of the East Coast, with spatial maximums in the Carolinas and from the Delmarva region (northern Chesapeake Bay and Delaware Bay) into New Jersey and Long Island Sound (Doswell et al. 2005). Derechos, intense mesoscale squall lines like the one that caused the 13 June 2013 meteotsunami (Fig. 1), also peak in June and July in similar regions as severe thunderstorms (Guastini and Bosart 2016). Both severe storms and derecho occurrence reduce rapidly as the calendar progresses into August and the fall months (Doswell et al. 2005; Guastini and Bosart 2016), which is when meteotsunami occurrence is correspondingly at its lowest point of the year for most of the East Coast. The increase in occurrence in the early summer is similar to what has been found in the Great Lakes (Bechle et al. 2016), which is not unexpected given that severe weather often propagates from the Midwest to the East Coast. Not surprisingly, the time-of-day dependence of meteotsunami occurrence in the summer months (Fig. 8) aligns closely with the peak occurrence of convective storms in the range of 1500-2100 eastern standard time (EST; Murray and Colle 2011) It is notable that the northeast region (north of Woods Hole) has very little meteotsunami occurrence in the summer months, which is likely due to the relatively low frequency of convective and severe storms (Doswell et al. 2005; Murray and Colle 2011). Though not a sizeable contributor to the total number, tropical cyclones also appear to force meteotsunamis in the summer and fall months (e.g., Hurricane Irma in 2017; Fig. 9), and are associated with about one event per year.

A second peak in meteotsunami occurrence is in the winter months (December-February; Fig. 8) for most open coast gauges along the East Coast from the Carolinas northward (Fig. 10). This peak corresponds well to winter storm occurrence, which reaches a maximum during the same months, especially for winter storms that impact most of the coastline (Hirsch et al. 2001). Average winter storm strength and speed are also at a maximum from December to February (Bernhardt and DeGaetano 2012), with storm speed potentially being an important consideration given the role resonance plays in meteotsunami generation. Winter storm tracks are often such that storms travel along the coast from the Carolinas up to New England (Eichler and Higgins 2006), which explains the often large number of gauges observing a meteotsunami event (e.g., Fig. 4). The more inland regions of Chesapeake and Delaware Bays tend to observe fewer winter storms than along the open coast (Eichler and Higgins 2006), which in part explains the small number of meteotsunamis observed in these regions during the winter months (Fig. 10).

The season of meteotsunami occurrence dictates what impacts from these events are most important to consider. Summertime meteotsunamis tend to be associated with thunderstorm or convective systems which are often short lived and isolated (Figs. 1, 7). In these cases the weather and coastal conditions could be unaffected only a relatively short distance away from the convective system and yet be substantially impacted by the meteotsunami event. Thus, there is potentially greater exposure for boaters, swimmers, beachgoers, and others to the hazard. Conversely, wintertime meteotsunamis are associated with large East Coast storm systems which directly impact broad areas (Fig. 4), and include other hazardous oceanographic conditions (storm surge, large waves). As such, a direct public safety impact is less likely; however, the contribution of the meteotsunami to storm surge and potential inundation may be important to consider. These same considerations hold true for meteotsunamis occurring from tropical cyclones (Fig. 9).

There are some important limitations to the method and results presented here. Relying only on point observations of meteotsunami events is one limitation. Many NOAA tide gauges are positioned to reduce the influence of high-frequency waterlevel oscillations to minimize wind-wave noise in the water-level signal. As such, some gauge locations might be protected from meteotsunami waves, potentially reducing amplitudes to the point of being below the $0.20-\mathrm{m}$ threshold. Further, in many cases individual gauges will likely not observe the maximum wave height occurring for a specific event, and the true size and impacts of larger events might remain uncertain. An example of this is the Boothbay 
Harbor meteotsunami of 28 October 2008. This event is widely documented as one of the more impactful meteotsunami events in recent history, with witnesses reporting a wave height of approximately $4 \mathrm{~m}$ (Vilibić et al. 2014b). Although this event was observed by NOAA tide gauges, the maximum observed wave height was only $0.23 \mathrm{~m}$ at the Portland, Maine, gauge less than $60 \mathrm{~km}$ away.

Another limitation of this approach is that, similar to seismic tsunami waves (Dunbar et al. 2017), waterlevel oscillations of varying frequencies near the meteotsunami band often occur concurrently with the meteotsunami, thus complicating the separation of the signals and identification of peak-to-trough wave height. For example, at Providence, there are often longer-period oscillations (with periods of 3-4 h) occurring simultaneously with a meteotsunami. This causes difficulties when attempting to measure peakto-trough wave height as these different oscillations interfere and cannot be separated. Other water-level variability that can be difficult to differentiate from the meteotsunami signal is the direct contribution of the atmospheric pressure change and wind to water level. For example, during the 13 June 2013 event the Lewes gauge observes the meteotsunami signal before all other gauges and it is coincident in time with the passing front in the radar imagery (Fig. 1). It is unclear if this is the signal of a progressive wave or just the influence of the pressure change on the water level. Another example is the storm surge that occurred in many southeast locations during Hurricane Charley on 14 August 2004. There were significant oscillations in the tsunami-frequency band identified at 12 gauges, but concurrent to those oscillations was an extremely rapid storm surge event which increased water levels in some locations by over $1.5 \mathrm{~m}$ in less than $90 \mathrm{~min}$. Clearly some of this rapid increase was caused by storm surge, but an apparent meteotsunami was concurrently observed. It was impossible to differentiate the signals from the time series alone and therefore this instance was removed from the meteotsunami climatology.

It is important to recognize that modifying the meteotsunami identification criteria will alter the number of events observed. For instance, using a minimum absolute wave height threshold greater than $0.20 \mathrm{~m}$ or choosing a relative wavelet energy threshold greater than six standard deviations will result in fewer observed events. Choosing to detect events with only an absolute threshold (equivalent for all gauges) or only a relative threshold (gauge independent) would also potentially impact the results. The primary goal of this study was to identify all potential events; however, in other cases it may be desirable to use higher thresholds to focus only on the most impactful or potentially damaging events.

Some potential approaches to better understand meteotsunami propagation and to separate different wave signals are to utilize additional observations or hydrodynamic numerical models. High-frequency (HF) radar has been utilized to observe some tsunami and meteotsunami events (Lipa et al. 2012, 2014). This climatology can be used to select appropriate HF radar observations to further investigate for meteotsunami signals. High-resolution numerical models have been utilized to better understand meteotsunami propagation (Anderson et al. 2015; Renault et al. 2011). Similar modeling approaches are presently being investigated for the U.S. East Coast, again relying on this climatology for potential events. In addition to better understanding meteotsunami events on the East Coast, there are plans to assess the performance of this approach on NOAA tide gauges in other coastal regions across the United States.

In conclusion, this automated meteotsunami detection approach will be invaluable to a range of future applications. In the near term, the database of East Coast events will be utilized by NOAA National Weather Service (NWS) to develop a meteotsunami impact catalogue. This catalogue will be used by NWS Weather Forecast Offices to better understand what underlying meteorological conditions lead to potentially impactful events, and how likely impactful events are to occur depending on region and season. The database of events will also be utilized to provide meteotsunamis with a range of different forcing mechanisms for the development and validation of hydrodynamic numerical models. Models will enable better understanding of how meteotsunamis are generated from different underlying meteorological conditions (e.g., summertime convective system or winter storm), and enable assessing wave height and potential impacts away from the gauge locations.

This automated approach also enables the potential for near-real-time meteotsunami detection at NOAA tide gauges. Tide gauge detection combined with the detection capability that already exists with offshore Deep Ocean Assessment of Tsunami (DART) buoys (Mungov et al. 2013) can enable the NWS to issue special meteotsunami warning statements upon event detection [as highlighted in Finucane (2018)]. Though the use of wavelets will result in some time lag in identification (presumably up to the maximum wave period of $2 \mathrm{~h}$ ), event identification even with a 2-h delay has the potential to be useful given that meteotsunami events often consist of multiple waves 
and can take substantial time to propagate along the coastline. Eventually, through a combination of observations and numerical modeling, a meteotsunami forecast system could be developed, similar to other efforts ongoing in other global locations (Jansá et al. 2007; Šepić and Vilibić 2011; Vilibić et al. 2016).

ACKNOWLEDGMENTS. The authors thank members of the Data Processing Team at the NOAA NOS Center for Operational Oceanographic Products and Services (CO-OPS) for their thorough and timely verification of water-level data used in this manuscript. We thank Dianna Parker of NOS CO-OPS for support with figure development and text review. We also thank the NOAA National Centers for Environmental Information (NCEI) natural hazards team, especially Kelly Stroker, George Mungov, and Aaron Sweeney, for their assistance with the quality-controlled 1-min water-level data. We would like to acknowledge Michael Angove and Lewis Kozlosky from the NOAA NWS Tsunami Program for their continued support on the topic of meteotsunamis. Last, we thank three anonymous reviewers for their comments and suggestions, which helped improve the quality of this manuscript. Water-level data utilized for this manuscript are collected, processed, and made available by the NOAA/ National Ocean Service Center for Operational Oceanographic Products and Services and can be found online (https://tidesandcurrents.noaa.gov). Quality-controlled 1-min water-level observations are performed by the NOAA National Centers for Environmental Information and data are also available online (www.ngdc.noaa.gov /hazard/tide.shtml).

\section{REFERENCES}

Anderson, E. J., A. J. Bechle, C. H. Wu, D. J. Schwab, G. E. Mann, and K. A. Lombardy, 2015: Reconstruction of a meteotsunami in Lake Erie on 27 May 2012: Roles of atmospheric conditions on hydrodynamic response in enclosed basins. J. Geophys. Res. Oceans, 120, 8020-8038, https://doi.org/10.1002/2015JC010883.

Bailey, K., C. DiVeglio, and A. Welty, 2014: An examination of the June 2013 East Coast meteotsunami captured by NOAA observing systems. NOAA Tech. Rep. NOS CO-OPS 079, 42 pp.

Bechle, A. J., D. A. R. Kristovich, and C. H. Wu, 2015: Meteotsunami occurrences and causes in Lake Michigan. J. Geophys. Res. Oceans, 120, 8422-8438, https://doi.org/10.1002/2015JC011317.

- , C. H. Wu, D. A. R. Kristovich, E. J. Anderson, D. J. Schwab, and A. B. Rabinovich, 2016: Meteotsunamis in the Laurentian Great Lakes. Sci. Rep., 6, 37832, https://doi.org/10.1038/srep37832.
Bernhardt, J. E., and A. T. DeGaetano, 2012: Meteorological factors affecting the speed of movement and related impacts of extratropical cyclones along the U.S. East Coast. Nat. Hazards, 61, 1463-1472, https:// doi.org/10.1007/s11069-011-0078-0.

Caires, S., 2007: Extreme wave statistics: Confidence intervals. Delft Hydraulics Rep. H4803.30, 33 pp.

Cho, K.-H., J.-Y. Choi, K.-S. Park, S.-K. Hyun, Y. Oh, and J.-Y. Park, 2013: A synoptic study on tsunami-like sea level oscillations along the west coast of Korea using an unstructured-grid ocean model. J. Coastal Res., 65, 678-683, https://doi.org/10.2112/SI65-115.1.

Choi, B.-J., C. Hwang, and S.-H. Lee, 2014: Meteotsunami-tide interactions and high-frequency sea level oscillations in the eastern Yellow Sea. J. Geophys. Res. Oceans, 119, 6725-6742, https://doi .org/10.1002/2013JC009788.

Churchill, D. D., S. H. Houston, and N. A. Bond, 1995: The Daytona Beach wave of 3-4 July 1992-A shallow-water gravity wave forced by a propagating squall line. Bull. Amer. Meteor. Soc., 76, 21-32, https://doi.org/10.1175/1520-0477(1995)076<0021: TDBWOJ>2.0.CO;2.

Coles, S., 2001: An Introduction to Statistical Modeling of Extreme Values. Springer-Verlag, $208 \mathrm{pp}$.

- , and E. Simiu, 2003: Estimating uncertainty in the extreme value analysis of data generated by a hurricane simulation model. J. Eng. Mech., 129, 1288-1294, https://doi.org/10.1061/(ASCE)0733 -9399(2003)129:11(1288).

Defant, A., 1961: Physical Oceanography. Vol. 2. Pergamon Press, 598 pp.

de Jong, M. P. C., and J. A. Battjes, 2004: Low-frequency sea waves generated by atmospheric convection cells. J. Geophys. Res., 109, C01011, https://doi .org/10.1029/2003JC001931.

Doswell, C. A., H. E. Brooks, and M. P. Kay, 2005: Climatological estimates of daily local nontornadic severe thunderstorm probability for the United States. Wea. Forecasting, 20, 577-595, https://doi .org/10.1175/WAF866.1.

Dunbar, P. K., and Coauthors, 2008: Long-term tsunami data archive supports tsunami forecast, warning, research, and mitigation. Pure Appl. Geophys., 165, 2275-2291, https://doi.org/10.1007/s00024-008-0419-4.

— , G. Mungov, A. Sweeney, K. Stroker, and N. Arcos, 2017: Challenges in defining tsunami wave heights. Pure Appl. Geophys., 174, 3043-3063, https://doi .org/10.1007/s00024-017-1614-y.

Edwing, R. F., 1991: Next Generation Water Level Measurement System (NGWLMS): Site design, preparation, and installation manual. NOAA Tech. Rep., 213 pp. 
Eichler, T., and W. Higgins, 2006: Climatology and ENSO-related variability of North American extratropical cyclone activity. J. Climate, 19, 20762093, https://doi.org/10.1175/JCLI3725.1.

Finucane, M., 2018: There was a meteotsunami last night off the coast. What's that? Boston Globe, 16 May, www.bostonglobe.com/metro/2018/05/16/there -was-meteotsunami-last-night-off-coast-what-that /tsxwTkkaTAhiCN4LoJ5LGI/story.html.

Geist, E. L., U. S. ten Brink, and M. Gove, 2014: A framework for the probabilistic analysis of meteotsunamis. Nat. Hazards, 74, 123-142, https://doi.org/10.1007 /s11069-014-1294-1.

Gill, S. K., and J. R. Schultz, Eds., 2000: Tidal datums and their applications. NOAA Rep. NOS CO-OPS $1,112 \mathrm{pp}$.

Goring, D. G., 2005: Rissaga (long-wave events) on New Zealand's eastern seaboard: A hazard for navigation. Proc. 17th Australasian Coastal Ocean Engineering Conf., Adelaide, Australia, Institution of Engineers Australia, 137-141.

Greenspan, H. P., 1956: The generation of edge waves by moving pressure distributions. J. Fluid Mech., 1, 574592, https://doi.org/10.1017/S002211205600038X.

Guastini, C. T., and L. F. Bosart, 2016: Analysis of a progressive derecho climatology and associated formation environments. Mon. Wea. Rev., 144, 1363-1382, https://doi.org/10.1175/MWR-D-15-0256.1.

Heidarzadeh, M., and K. Satake, 2013: The 21 May 2003 tsunami in the western Mediterranean Sea: Statistical and wavelet analyses. Pure Appl. Geophys., 170, 14491462, https://doi.org/10.1007/s00024-012-0509-1.

Heitsenrether, R., and E. Davis, 2011: Test and evaluation report: Limited acceptance of the design analysis WaterLog H-3611i microwave radar water level sensor. NOAA Tech. Rep. NOS CO-OPS 061, 97 pp.

Hibiya, T., and K. Kajiura, 1982: Origin of "abiki" phenomena (kind of seiches) in Nagasaki Bay. J. Oceanogr. Soc. Japan, 38, 172-182, https://doi .org/10.1007/BF02110288.

Hirsch, M. E., A. T. DeGaetano, and S. J. Colucci, 2001: An East Coast winter storm climatology. J. Climate, 14, 882-899, https://doi.org/10.1175/1520 -0442(2001)014<0882:AECWSC >2.0.CO;2.

Jansá, A., S. Monserrat, and D. Gomis, 2007: The rissaga of 15 June 2006 in Ciutadella (Menorca), a meteorological tsunami. Adv. Geosci., 12, 1-4, https://doi .org/10.5194/adgeo-12-1-2007.

Kumar, P., and E. Foufoula-Georgiou, 1997: Wavelet analysis for geophysical applications. Rev. Geophys., 35, 385-412, https://doi.org/10.1029/97RG00427.

Linares, Á., A. J. Bechle, and C. H. Wu, 2016: Characterization and assessment of the meteotsunami hazard in northern Lake Michigan. J. Geophys. Res. Oceans, 121, 7141-7158, https://doi.org/10.1002/2016JC011979.

Lipa, B., J. Isaacson, B. Nyden, and D. Barrick, 2012: Tsunami arrival detection with high frequency (HF) radar. Remote Sens., 4, 1448-1461, https://doi .org/10.3390/rs4051448.

—, H. Parikh, D. Barrick, H. Roarty, and S. Glenn, 2014: High-frequency radar observations of the June 2013 US East Coast meteotsunami. Nat. Hazards, 74, 109-122, https://doi.org/10.1007/s11069-013-0992-4.

Marcos, M., S. Monserrat, R. Medina, A. Orfila, and M. Olabarrieta, 2009: External forcing of meteorological tsunamis at the coast of the Balearic Islands. Phys. Chem. Earth, 34, 938-947, https://doi.org/10.1016/j .pce.2009.10.001.

Monserrat, S., I. Vilibić, and A. B. Rabinovich, 2006: Meteotsunamis: Atmospherically induced destructive ocean waves in the tsunami frequency band. Nat. Hazards Earth Syst. Sci., 6, 1035-1051, https:// doi.org/10.5194/nhess-6-1035-2006.

Mungov, G., M. Eble, and R. Bouchard, 2013: DART tsunameter retrospective and real-time data: A reflection on 10 years of processing in support of tsunami research and operations. Pure Appl. Geophys., 170, 1369-1384, https://doi.org/10.1007 /s00024-012-0477-5.

Murray, J. C., and B. A. Colle, 2011: The spatial and temporal variability of convective storms over the northeast United States during the warm season. Mon. Wea. Rev., 139, 992-1012, https://doi .org/10.1175/2010MWR3316.1.

Nomitsu, T., 1935: A theory of tsunamis and seiches produced by wind and barometric gradient. Mem. Coll. Sci. Imp. Univ. Kyoto, 18A, 201-214.

Olabarrieta, M., A. Valle-Levinson, C. J. Martinez, C. Pattiaratchi, and L. M. Shi, 2017: Meteotsunamis in the northeastern Gulf of Mexico and their possible link to El Niño Southern Oscillation. Nat. Hazards, 88, 1325-1346, https://doi.org/10.1007/s11069-017-2922-3.

Ozsoy, O., I. D. Haigh, M. P. Wadey, R. J. Nicholls, and N. C. Wells, 2016: High-frequency sea level variations and implications for coastal flooding: A case study of the Solent, UK. Cont. Shelf Res., 122, 1-13, https:// doi.org/10.1016/j.csr.2016.03.021.

Park, J., R. Heitsenrether, and W. Sweet, 2014: Water level and wave height estimates at NOAA tide stations from acoustic and microwave sensors. J. Atmos. Oceanic Technol., 31, 2294-2308, https://doi .org/10.1175/JTECH-D-14-00021.1.

Parker, B., 2007: Tidal analysis and prediction. NOAA Rep. NOS CO-OPS 3, 378 pp.

Pasquet, S., and I. Vilibić, 2013: Shelf edge reflection of atmospherically generated long ocean waves along 
the central U.S. East Coast. Cont. Shelf Res., 66, 1-8, https://doi.org/10.1016/j.csr.2013.06.007.

—_ — - and J. Šepić, 2013: A survey of strong high-frequency sea level oscillations along the US East Coast between 2006 and 2011. Nat. Hazards Earth Syst., 13, 473-482, https://doi.org/10.5194 /nhess-13-473-2013.

Pattiaratchi, C., and E. M. S. Wijeratne, 2014: Observations of meteorological tsunamis along the southwest Australian coast. Nat. Hazards, 74, 281-303, https://doi.org/10.1007/s11069-014-1263-8.

- , and - 2015: Are meteotsunamis an underrated hazard? Philos. Trans. Roy. Soc., 373A, 20140377, https://doi.org/10.1098/rsta.2014.0377.

Paxton, C. H., and D. A. Sobien, 1998: Resonant interaction between an atmospheric gravity wave and shallow water wave along Florida's west coast. Bull. Amer. Meteor. Soc., 79, 2727-2732, https://doi .org/10.1175/1520-0477(1998)079<2727:RIBAAG $>2.0 . \mathrm{CO} ; 2$.

Proudman, J., 1929: The effects on the sea of changes in atmospheric pressure. Geophys. Suppl. Mon. Not. Roy. Astron. Soc., 2, 197-209, https://doi.org/10.1111 /j.1365-246X.1929.tb05408.x.

Rabinovich, A. B., and S. Monserrat, 1996: Meteorological tsunamis near the Balearic and Kuril Islands: Descriptive and statistical analysis. Nat. Hazards, 13, 55-90, https://doi.org/10.1007/BF00156506.

— , and — , 1998: Generation of meteorological tsunamis (large amplitude seiches) near the Balearic and Kuril Islands. Nat. Hazards, 18, 27-55, https:// doi.org/10.1023/A:1008096627047.

— , and R. E. Thomson, 2007: The 26 December 2004 Sumatra tsunami: Analysis of tide gauge data from the World Ocean part 1. Indian Ocean and South Africa. Pure Appl. Geophys., 164, 261-308, https:// doi.org/10.1007/s00024-006-0164-5.

-, - and F. E. Stephenson, 2006: The Sumatra tsunami of 26 December 2004 as observed in the North Pacific and North Atlantic oceans. Surv. Geophys., 27, 647-677, https://doi.org/10.1007 /s10712-006-9000-9.

Raichlen, F., 1966: Harbor resonance. Estuary and Coastline Hydrodynamics, A. T. Ippen, Ed., McGraw Hill, 281-340.

Renault, L., G. Vizoso, A. Janśa, J. Wilkin, and J. Tintore, 2011: Toward the predictability of meteotsunamis in the Balearic Sea using regional nested atmosphere and ocean models. Geophys. Res. Lett., 38, L10601, https://doi.org/10.1029 /2011GL047361.

Sallenger, A. H., J. H. List, G. Gelfenbaum, R. P. Stumpf, and M. Hansen, 1995: Large wave at Daytona Beach,
Florida, explained as a squall-line surge. J. Coastal Res., 11, 1383-1388.

Šepić, J., and I. Vilibić, 2011: The development and implementation of a real-time meteotsunami warning network for the Adriatic Sea. Nat. Hazards Earth Syst., 11, 83-91, https://doi.org/10.5194/nhess -11-83-2011.

- — , and D. Belušić, 2009: Source of the 2007 Ist meteotsunami (Adriatic Sea). J. Geophys. Res., 114, C03016, https://doi.org/10.1029/2008JC005092.

- - — meteorological tsunamis: Observations, link to the atmosphere, and predictability. J. Geophys. Res., 117, C02002, https://doi.org/10.1029/2011JC007608.

- — _ A. B. Rabinovich, and S. Monserrat, 2015: Widespread tsunami-like waves of 23-27 June in the Mediterranean and Black Seas generated by highaltitude atmospheric forcing. Sci. Rep., 5, 11682, https://doi.org/10.1038/srep11682.

Tanaka, K., 2010: Atmospheric pressure-wave bands around a cold front resulted in a meteotsunami in the East China Sea in February 2009. Nat. Hazards Earth Syst., 10, 2599-2610, https://doi.org/10.5194 /nhess-10-2599-2010.

Tappin, D. R., A. Sibley, K. Horsburgh, C. Daubord, D. Cox, and D. Long, 2013: The English Channel "tsunami" of 27 June 2011-A probable meteorological source. Weather, 68, 144-152, https://doi .org/10.1002/wea.2061.

Thomson, R. E., and W. J. Emery, 2014: Data Analysis Methods in Physical Oceanography. Elsevier, 728 pp. —, A. B. Rabinovich, and M. V. Krassovski, 2007: Double jeopardy: Concurrent arrival of the 2004 Sumatra tsunami and storm-generated waves on the Atlantic coast of the United States and Canada. Geophys. Res. Lett., 34, L15607, https://doi .org/10.1029/2007GL030685.

- , I. V. Fine, D. C. Sinnott, A. McCarthy, N. A. S. Sutherland, and L. K. Neil, 2009: Meteorological tsunamis on the coasts of British Columbia and Washington. Phys. Chem. Earth, 34, 971-988, https:// doi.org/10.1016/j.pce.2009.10.003.

Torrence, C., and G. P. Compo, 1998: A practical guide to wavelet analysis. Bull. Amer. Meteor. Soc., 79, 61-78, https://doi.org/10.1175/1520-0477(1998) 079<0061:APGTWA>2.0.CO;2.

Vilibić, I., S. Monserrat, and A. B. Rabinovich, 2014a: Meteorological tsunamis on the US East Coast and in other regions of the World Ocean. Nat. Hazards, 74, 1-9, https://doi.org/10.1007/s11069-014 $-1350-\mathrm{x}$.

—, K. Horvath, N. S. Mahović, S. Monserrat, M. Marcos, A. Amores, and I. Fine, 2014b: Atmospheric 
processes responsible for generation of the 2008 Boothbay meteotsunami. Nat. Hazards, 74, 25-53, https://doi.org/10.1007/s11069-013-0811-y.

—, J. Šepić, A. B. Rabinovich, and S. Monserrat, 2016: Modern approaches in meteotsunami research and early warning. Front. Mar. Sci., 3, 57, https://doi .org/10.3389/fmars.2016.00057.

Vučetić, T., I. Vilibić, S. Tinti, and A. Maramai, 2009: The Great Adriatic Flood of 21 June 1978 revisited: An overview of the reports. Phys. Chem. Earth, 34, 894-903, https://doi.org/10.1016/j.pce.2009.08.005.
Wang, X. Z., K. P. Li, Z. W. Yu, and J. Wu, 1987: Statistical characteristics of seiches in Longkou Harbor. J. Phys. Oceanogr., 17, 1063-1065, https:// doi.org/10.1175/1520-0485(1987)017<1063:SCOSIL $>2.0 . \mathrm{CO} ; 2$.

Wertman, C. A., R. M. Yablonsky, Y. Shen, J. Merrill, C. R. Kincaid, and R. A. Pockalny, 2014: Mesoscale convective system surface pressure anomalies responsible for meteotsunamis along the U.S. East Coast on June 13th, 2013. Sci. Rep., 4, 7143, https:// doi.org/10.1038/srep07143.

\section{UNDERSTANDING EARTH'S Atmosphere \& Ocean System}

Comprehensive kit with hands-on learning tools

O Can be used at home, in class, or as a lab

O 10 basic Meteorology and Oceanography topics and over 25 activities

O Can be purchased individually or as a classroom set of 16 (including instructor set)

O Contains reuseable materials designed by AMS and found nowhere else!

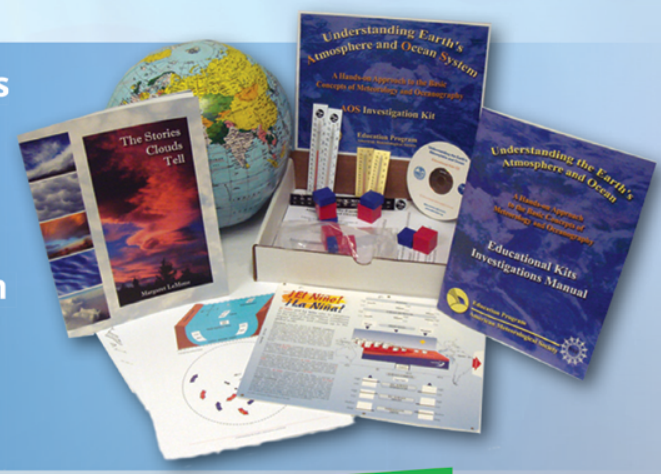

\section{To Order (check, PO, credit card):}

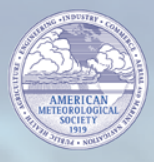

Phone: 1-800-824-0405

Fax: Mail:

American Meteorological Society Education Program

1-800-258-1176 1200 New York Ave., NW, Ste 500, Washington, DC 20005-3928

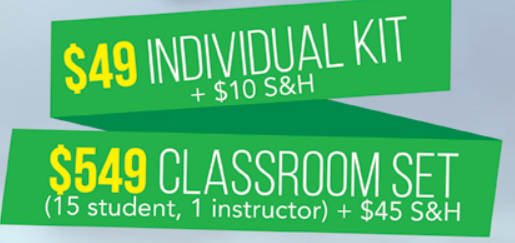




\section{JOIN US FOR THE CULMINATION OF OUR CENTENNIAL CELEBRATION}

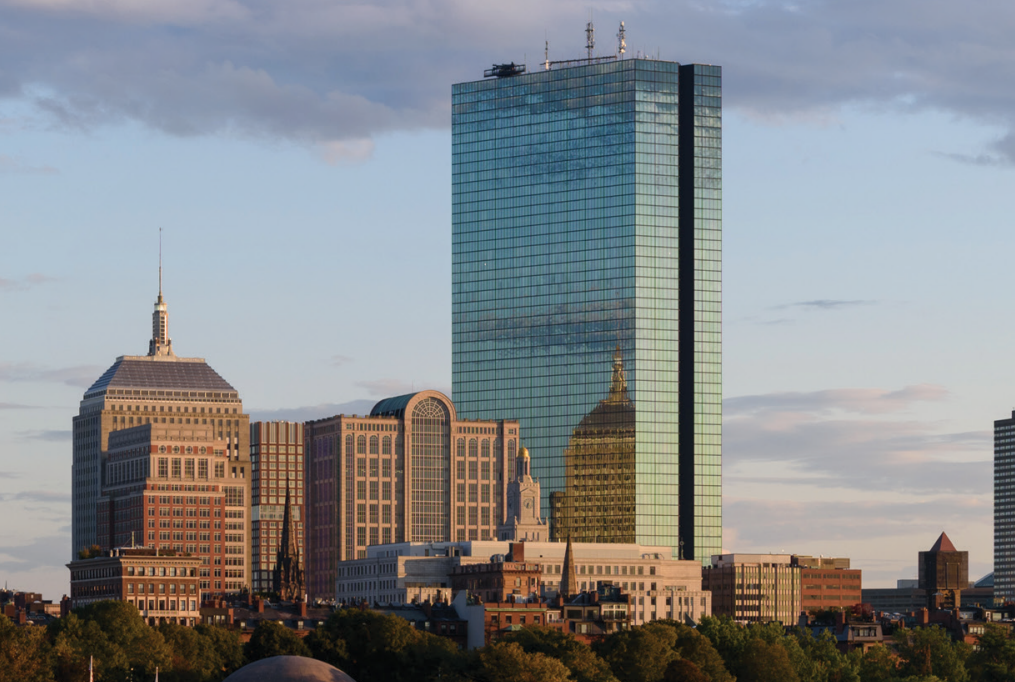

